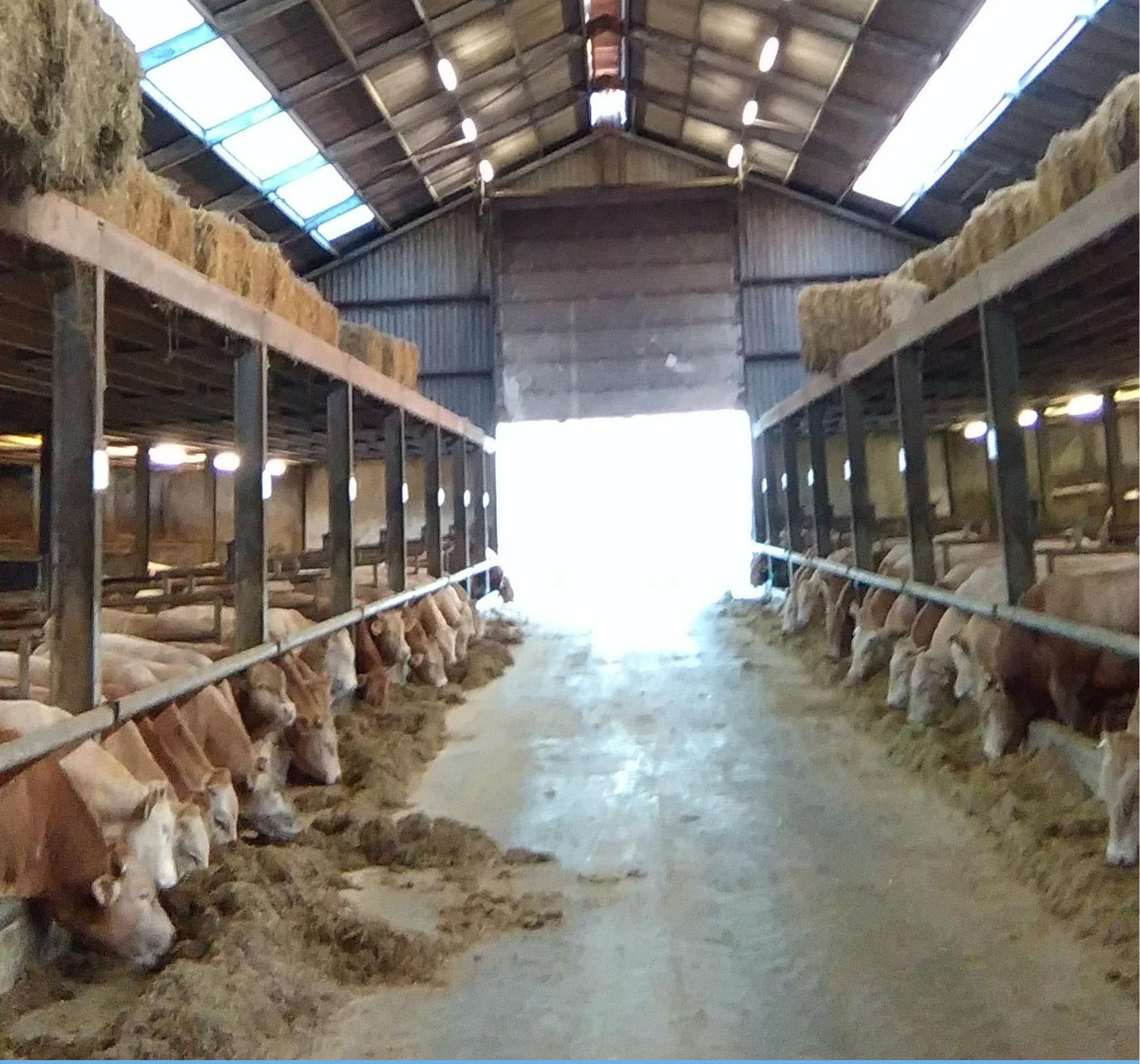

Ammoniakemissie uit natuurlijk geventileerde hellingstallen voor vleesvee

André Aarnink, Annemieke Hol, Sjoerd Bokma 



\section{Ammoniakemissie uit natuurlijk geventileerde hellingstallen voor vleesvee}

André Aarnink

Annemieke $\mathrm{Hol}$

Sjoerd Bokma

Wageningen Livestock Research

Dit onderzoek is uitgevoerd door Wageningen Livestock Research, in opdracht van en gefinancierd door LTOvakgroep Vleesvee, vertegenwoordigd door Mts. F. Tillemans en met medefinanciering van RVO.

Wageningen Livestock Research

Wageningen, oktober 2017

Rapport 1078 
Aarnink, A.J.A., J.M.G. Hol, S. Bokma, 2017. Ammoniakemissie uit natuurlijk geventileerde hellingstallen voor vleesvee. Wageningen Livestock Research, Rapport 1078.

Samenvatting NL In dit onderzoek zijn de gasvormige en stof emissies bepaald uit een hellingstal voor vleesstieren. Er kan geconcludeerd worden dat de ammoniakemissie waarschijnlijk hoger is dan de huidige emissiefactor voor vleesstieren. De emissie van methaan is vergelijkbaar met die voor melkvee en de emissies van lachgas en fijnstof zijn laag.

Summary UK In this study the gaseous and dust emissions from straw bedded sloped floor housing for beef cattle were studied. It is concluded that ammonia emissions are probably higher than the present emission factor for beef cattle. The emission of methane is comparable to that for dairy cattle and the emissions of nitrous oxide and particulate matter are low.

Dit rapport is gratis te downloaden op https://doi.org/10.18174/431449 of op www.wur.nl/livestock-research (onder Wageningen Livestock Research publicaties).

(c) 2017 Wageningen Livestock Research

Postbus 338, 6700 AH Wageningen, T 03174839 53, E info.livestockresearch@wur.nl, www.wur.nl/livestock-research. Wageningen Livestock Research is onderdeel van Wageningen University \& Research.

Wageningen Livestock Research aanvaardt geen aansprakelijkheid voor eventuele schade voortvloeiend uit het gebruik van de resultaten van dit onderzoek of de toepassing van de adviezen.

Alle rechten voorbehouden. Niets uit deze uitgave mag worden vermenigvuldigd en/of openbaar gemaakt worden door middel van druk, fotokopie, microfilm of op welke wijze dan ook zonder voorafgaande toestemming van de uitgever of auteur.

De certificering volgens ISO 9001 door DNV onderstreept ons kwaliteitsniveau. Op als onze onderzoeksopdrachten zijn de Algemene Voorwaarden van de Animal Sciences Group van toepassing. Deze zijn gedeponeerd bij de Arrondissementsrechtbank Zwolle.

Wageningen Livestock Research Rapport 1078 


\section{Inhoud}

$\begin{array}{ll}\text { Samenvatting } & 5\end{array}$

$\begin{array}{ll}1 & \text { Inleiding }\end{array}$

$\begin{array}{lll}2 & \text { Materiaal en Methode } & 8\end{array}$

2.1 Materiaal $\quad 8$

2.2 Methode 9

2.2.1 Uitvoering metingen 9

2.2.2 Data analyse $\quad 11$

$\begin{array}{llr}3 & \text { Resultaten } & 13\end{array}$

$\begin{array}{lll}3.1 & \text { Metingen } & 13\end{array}$

$\begin{array}{lll}3.2 & \text { Ventilatie en emissies } & 15\end{array}$

$\begin{array}{llr}4 & \text { Discussie } & 16\end{array}$

$\begin{array}{llr}5 & \text { Conclusies } & 18\end{array}$

$\begin{array}{ll}\text { Literatuur } & 19\end{array}$

$\begin{array}{lll}\text { Bijlage } 1 & \text { Omschrijving meetlocaties } & 20\end{array}$

Bijlage 2 Gedetailleerde meetdata rantsoen en $\mathrm{CO}_{2}$-productie 32 


\section{Samenvatting}

Het doel van dit onderzoek was het bepalen van de ammoniakemissie uit hellingstallen voor vleesstieren. Op basis van deze metingen zou dit systeem opgenomen kunnen worden met een aparte emissiefactor in de bijlage van de Rav (Regeling ammoniak en veehouderij) en daarmee een bredere toepassing van deze diervriendelijke stalsystemen in de praktijk mogelijk maken. Naast ammoniak zijn tevens metingen gedaan aan de emissies van broeikasgassen (methaan en lachgas) en fijnstof.

De metingen zijn uitgevoerd op vier bedrijven. Op elk bedrijf is één hellingstal voor vleesstieren (8 24 maanden, Rav categorie A6) bemeten. De hellingstal heeft hokken met stieren die gehouden worden op een ingestrooide, enigszins hellende ligvloer. Het strobed in de ligruimte wordt eenmaal per dag aangevuld met 3-4 kg stro per dierplaats. De mest en urine worden vermengd met stro door de dieren langs de helling naar beneden getrapt naar een dichte betonnen vloer achter het voerhek. Daar wordt de stromest met behulp van een mestschuif verwijderd en afgevoerd naar een buitenopslag.

De concentraties ammoniak, broeikasgassen $\left(\mathrm{CH}_{4}\right.$ en $\left.\mathrm{N}_{2} \mathrm{O}\right)$ en fijnstof (PM10) van de in- en uitgaande lucht zijn gemeten. Het ventilatiedebiet is bepaald met behulp van de $\mathrm{CO}_{2}$-balans methode. Hierbij wordt uitgegaan van een bekende $\mathrm{CO}_{2}$-productie in de stal (door de dieren en vanuit het strobed) en de gemeten concentraties $\mathrm{CO}_{2}$ in de in- en uitgaande stallucht.

Voor een volledige protocollaire meting voor bepaling van een emissiefactor van een bepaald stalsysteem moet er gedurende minimaal 6 dagen verspreid over het jaar een 24-uurs meting worden uitgevoerd op elk van 4 bedrijven. Aangezien uit de eerste twee metingen per bedrijf is gebleken dat de gemeten ammoniakemissies in dit onderzoek niet aan de verwachtingen voldeden, is door de opdrachtgever besloten om geen onnodige kosten te maken en het onderzoek stop te zetten na deze eerste twee metingen.

Uit de resultaten blijkt dat het berekende ventilatiedebiet gemiddeld $2390 \mathrm{~m}^{3} / \mathrm{uur}$ per vleesstier was. De ammoniakemissie varieerde vrij sterk tussen de verschillende metingen van 12,7 tot 29,6 kg/jaar per dierplaats, met een gemiddelde van 21,4 . Gemiddeld waren de ammoniakemissies van de verschillende bedrijven redelijk vergelijkbaar. De gemiddelde methaanemissie was $111 \mathrm{~kg} / \mathrm{jaar}$ per dierplaats. Lachgas- en PM10-emissies konden niet nauwkeurig worden bepaald, omdat de concentraties in de uitgaande lucht vrijwel niet verhoogd waren ten opzichte van de concentraties in de ingaande lucht.

Aangezien in dit onderzoek slechts een beperkt deel van de oorspronkelijke geplande metingen is uitgevoerd (8 van de 24), konden geen nauwkeurige emissies worden bepaald voor dit systeem. Echter, het volgende kan voorzichtig worden geconcludeerd:

- De ammoniakemissie in een hellingstal voor vleesstieren lijkt hoger te zijn dan de huidige generieke emissiefactor voor vleesstieren.

- De methaanemissie van vleesstieren lijkt vergelijkbaar te zijn met die voor melkkoeien.

- De emissies van lachgas en fijnstof (PM10) zijn in deze natuurlijk, ruim geventileerde stallen voor vleesstieren moeilijk nauwkeurig te bepalen door de geringe verschillen tussen uitgaande en ingaande luchtconcentraties. Dit betekende echter wel dat de emissies van lachgas en fijnstof laag zijn. 


\section{$1 \quad$ Inleiding}

De Nederlandse roodvleessector heeft in de achterliggende decennia belangrijke ontwikkelingen doorgemaakt. Er is een ommezwaai gemaakt naar meer welzijnsvriendelijke houderij van de dieren. Werden in het verleden de dieren veelal op volledig roostervloeren gehuisvest, tegenwoordig zijn de dieren vaak gehuisvest in hokken met dichte vloeren en stro. Hiermee heeft de sector aanmerkelijk aan draagvlak en maatschappelijk aanzien gewonnen.

De extra aandacht voor dierenwelzijn en diergezondheid vanuit de sector heeft, met als tussenstap de potstal, geleid tot de ontwikkeling van de hellingstal. Feitelijk tot stand gekomen door innovatie vanuit de sector zelf en zonder veel ondersteuning vanuit overheid en onderzoek. De potstal en de hellingstal hebben zich bewezen als een diervriendelijke systeem, maar ook als een praktisch houderijsysteem voor de veehouder. De praktijk kent veel potstallen. Bij nieuwbouw of renovatie van stallen voor zoogkoeien en vleesvee wordt de laatste jaren overwegend voor een hellingstal-uitvoering gekozen. De sector heeft het beeld dat met deze fundamentele wijzigingen in huisvesting en houderij niet alleen het dierenwelzijn is gediend, maar ook het milieu. Dit is tot op heden niet vastgesteld en dat vormt daarom het kernpunt van dit meetproject.

Vanuit de overheid lag de prioriteit voor emissiereductie bij de grote veehouderijsectoren. De roodvleesveesector zelf bestaat uit veel, maar relatief kleine bedrijven (en heeft beperkte collectieve middelen). Ook voor het bedrijfsleven was en is er geen incentive om in (relatief dure) ammoniakmetingen aan een hellingstal te investeren. De hellingstal is immers een ontwerpprincipe dat eenvoudig te kopiëren is.

De Natuurbeschermings- (NB-) wet en de provinciale en nationale regelgeving die daaruit naar voren komen werpen nieuw licht op de zaak. Veel bedrijven met zoogkoeien en vleesvee liggen in de directe nabijheid van kwetsbare natuur. Hoewel de bedrijven veelal beperkt van omvang zijn, kunnen ze, vanwege de korte afstand tot natuur, toch een substantiële bijdrage leveren aan de vaak overbelaste situatie. Dit kan schadelijk zijn voor het imago van de vleesveehouderij. Bovendien werkt het belemmerend op de ontwikkelmogelijkheden van de bedrijven. Op dit moment zijn er voor vleesvee geen erkende emissie-reducerende technieken beschikbaar.

Het doel van dit onderzoek was het bepalen van de ammoniakemissie uit hellingstallen voor vleesstieren. Naast ammoniak zijn tevens metingen gedaan aan de emissies van broeikasgassen (methaan en lachgas) en fijnstof. Het onderzoek is uitgevoerd in opdracht van LTO-vakgroep vleesvee en medegefinancierd door EZ-RVO. 


\section{$2 \quad$ Materiaal en Methode}

\section{$2.1 \quad$ Materiaal}

De metingen zijn uitgevoerd op vier bedrijven. Op elk bedrijf is één hellingstal voor vleesstieren ( 8 24 maanden) (Rav categorie A6) bemeten. De hellingstal is binnen deze Rav categorie één van de subtypen en heeft hokken met stieren die gehouden worden op een ingestrooide hellende ligvloer. In bijlage 1 volgt een uitgebreide beschrijving gegeven van de meetlocaties zoals ze ook zijn ingediend bij de beoordeling van het meetplan bij de TAC-RAV. Hieronder volgt een algemene omschrijving van de locaties met daarbij een tabel met de specificaties per bedrijf. Hierin is ook aangegeven waar in de stal is gemeten. Het was belangrijk om te voorkomen dat tijdens de metingen de inkomende lucht in de te bemeten stal bevuild zou raken met vervuilende componenten die geëmitteerd zijn uit nabijgelegen stallen. De stallen hebben daardoor ieder een bepaalde windrichting waarbij bij voorkeur is gemeten. Deze voorkeurs windrichting is voor elke locatie vermeld. Per locatie en per windrichting is bepaald wat de locatie wordt voor de concentratiemetingen van de ingaande lucht. Zo mogelijk wordt dit meetpunt op tenminste $10 \mathrm{~m}$ van de stal geplaatst.

De stierenstal is ingericht met hokken waarin per hok een groep dieren wordt gehuisvest. Een hok bestaat uit een ingestrooide hellende dichte vloer als ligruimte en een mestgang, die grenst aan het voerhek, bestaande uit een dichte betonvloer. De combinatie van een ingestrooid deel (ingestrooid met stro) en een dichte vloer als mestgang wordt hellingstal genoemd waarbij de dieren het stro voor een deel uit de ingestrooide ruimte naar de mestgang lopen. Deze mestgang wordt bij toepassing van een automatische schuif een aantal keren per dag en anders wekelijks leeg geschoven. De ligruimte wordt dagelijks ingestrooid. De dieren worden eenmaal per dag gevoerd. De stal wordt natuurlijk geventileerd met inlaatopeningen aan beide lengtezijden van de stal. Eén van de locaties is een open frontstal (stal 4) waarbij 1 zijde een traditionele inlaatopening heeft en de andere zijde een open front. De traditionele inlaat op de andere locaties begint op ca. $2 \mathrm{~m}$ hoogte en is ca. $1 \mathrm{~m}$ hoog. De lucht gaat grotendeels via de nok naar buiten. In tabel 1 zijn de belangrijkste karakteristieken van de stallen, waaraan in dit onderzoek is gemeten, weergegeven.

Op alle bedrijven werd een gemengd rantsoen gevoerd met behulp van een voermengwagen. In de stallen werden vleesstieren gehouden van de rassen Blonde d 'Aquitaine en Belgische Witblauwe. Het groeitraject van de dieren lag tussen de 8 en 24 mnd. De dieren startten op een gewicht tussen $250-$ $450 \mathrm{~kg}$ en werden afgeleverd op een gewicht tussen 720 - $875 \mathrm{~kg}$. Er wordt geen all in - all out toegepast maar continu afgeleverd en opnieuw opgezet. Daardoor is er sprake van een vrij stabiel gemiddeld gewicht van de aanwezige dieren.

Tabel 1 Omschrijving van de doorgemeten stallen, aanvullende informatie staat in bijlage 1.

\begin{tabular}{|c|c|c|c|c|}
\hline Kop & Stal 1 & Stal 2 & Stal 3 & Stal 4 \\
\hline Indeling stal & $\begin{array}{l}2 \text { rijen van } 17 \text { hokken } \\
\text { Voergang } 5 \mathrm{~m} \text { breed }\end{array}$ & $\begin{array}{l}2 \text { rijen van } 11 \text { hokken } \\
\text { Voergang } 5 \mathrm{~m} \text { breed }\end{array}$ & $\begin{array}{l}2 \text { rijen van } 17 \text { hokken } \\
\text { Voergang } 5 \mathrm{~m} \text { breed }\end{array}$ & $\begin{array}{l}2 \text { rijen van } 14 \text { en } 1 \\
\text { rij van } 12 \text { hokken } \\
\text { voergang } 5 \text { m breed }\end{array}$ \\
\hline Leefoppervlak per dier & $6,4 \mathrm{~m} 2$ & $7,2 \mathrm{~m} 2$ & $6,6 \mathrm{~m} 2$ & $6,8 \mathrm{~m} 2$ \\
\hline Oppervlak stro / mestgang & $16,0 / 16,0 \mathrm{~m} 2$ & $31,2 / 19,4 \mathrm{~m} 2$ & $28,6 / 17,6 \mathrm{~m} 2$ & $18,8 / 15,2$ \\
\hline Uitmestfrequentie mestgang & $\begin{array}{l}\text { 1x per week met } \\
\text { shovel }\end{array}$ & $\begin{array}{l}1 \times \text { per week met } \\
\text { shovel }\end{array}$ & $\begin{array}{l}1 \times \text { per week met } \\
\text { shovel }\end{array}$ & $\begin{array}{l}4 \times \text { per dag met } \\
\text { mestschuif }\end{array}$ \\
\hline
\end{tabular}




\section{$2.2 \quad$ Methode}

\subsubsection{Uitvoering metingen}

Voor een volledige protocollaire meting voor bepaling van een emissiefactor van een bepaald stalsysteem moet er gedurende minimaal 6 dagen verspreid over het jaar een 24-uurs meting worden uitgevoerd op elk van 4 bedrijven. Aangezien uit de eerste twee metingen per bedrijf is gebleken dat de gemeten ammoniakemissies in dit onderzoek niet aan de verwachtingen voldeden, is door de opdrachtgever besloten om geen onnodige kosten te maken en het onderzoek stop te zetten na deze eerste twee metingen.

De volgende metingen zijn gedaan in de 4 hellingstallen voor vleesstieren gedurende 2 meetdagen van 24 uur:

- Ammoniakconcentratie. Voor bepaling van de ammoniakconcentratie in de uitgaande stallucht is gebruik gemaakt van de zogenaamde nat-chemische meetmethode. Hiervoor is op drie plekken verdeeld over de lengte van de stal de uitgaande lucht gedurende $24 \mathrm{~h}$ bemonsterd, gebruik makend van een NH3-vangsysteem met gaswasflessen. Voor de ammoniakconcentratie van de ingaande stallucht (achtergrond, in duplo), gemeten aan de zijde waar de wind vandaan kwam, is tevens gebruik gemaakt van dit meetsysteem. Bij de nat-chemische meetmethode wordt de lucht actief bemonsterd over de gehele periode (24h). De methode maakt gebruik van de absorptie van ammoniak in een zure vloeistof. Het luchtmonster uit de nok van de stal wordt met behulp van een pomp via een Teflonleiding door de monsternameflessen met zure oplossing geleid. De ammoniak in de lucht wordt gebonden in de zure vloeistof. De flow, waarmee wordt bemonsterd, wordt door middel van een kritisch capillair vast ingesteld. De daadwerkelijke flow wordt gemeten met een digitale flowmeter (DryCal ${ }^{\circledR}$ Defender 510). Dit wordt bij de start en aan het einde van elke meting

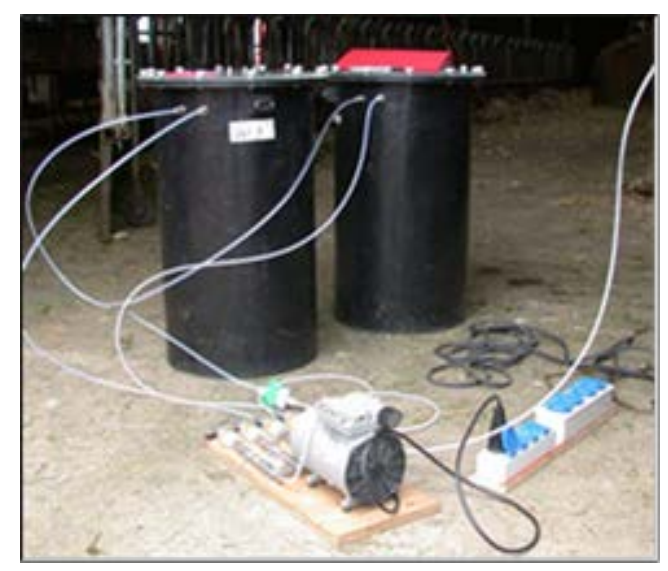
gedaan Als absorptie vloeistof wordt $100 \mathrm{ml} \mathrm{0,05} \mathrm{M}$ salpeterzuur gebruikt. Om zeker te zijn dat alle ammoniak wordt opgevangen in het zuur worden twee gaswasflessen in serie geplaatst. Met de tweede gaswasfles kan een eventuele doorslag van ammoniak door de eerste fles worden vastgesteld. In het chemisch laboratorium van WUR wordt met behulp van een spectrofotometer het gehalte aan gebonden ammoniak bepaald (volgens NEN-ISO 7150-1:2002).

Figuur 1. Foto van de meting van de broeikasgassen volgens de longmethode.

- Concentratie broeikasgassen $\left(\mathbf{C O}_{2}, \mathbf{C H}_{\mathbf{4}}\right.$ en $\left.\mathbf{N}_{\mathbf{2}} \mathbf{O}\right)$. Broeikasgassen zijn in de uitgaande stallucht gemeten door gedurende $24 \mathrm{~h}$ verzamelmonsters te nemen, op 3 plekken verdeeld over de lengte van de stal onder de nok met behulp van de zogenaamde longmethode. Bij deze methode wordt de lucht actief bemonsterd over de gehele meetperiode van 24h. Een Nalophan monsternamezak van 40 liter wordt hierbij in een gesloten vat geplaatst (zie Figuur 1). De stallucht wordt bemonsterd door gebruik te maken van Teflon leidingen die via een vaste flow $(20 \mathrm{ml} / \mathrm{min})$ de lucht aanzuigen vanuit de nok. Een pomp bevestigd aan het vat zorgt er voor dat het vat vacuüm wordt gezogen waardoor de zak waaraan de monsternameleiding is bevestigd wordt volgezogen. $\mathrm{Na}$ bemonstering wordt in het chemisch laboratorium van WUR de lucht geanalyseerd op een gaschromatograaf (Interscience/Carlo Erba Instruments Inc., Breda, the Netherlands, GC 8000 Top; column Molsieve 5A; detector: TCD (thermal conductivity detector). De broeikasgasconcentraties werden op dezelfde locaties gemeten als ammoniak. De broeikasgasconcentraties in de ingaande stallucht (achtergrond) werden buiten bovenwinds van de stal bemonsterd volgens dezelfde methode (in duplo). 


\section{- $\mathrm{CO}_{2}$ productie strobed}

$\mathrm{Er}$ zijn metingen uitgevoerd naar de $\mathrm{CO}_{2}$ productie in het strobed. Dit is van belang om op een correcte wijze het ventilatiedebiet van de stal met behulp van de $\mathrm{CO}_{2}$ balansmethode te kunnen berekenen. De verwachting was dat de hoeveelheid $\mathrm{CO}_{2}$ dat door het strobed wordt geproduceerd beperkt is en niet sterk varieert in de tijd. Tussen meetlocaties zouden er wel verschillen kunnen zijn, omdat het stromanagement verschilt van bedrijf tot bedrijf. Aansluitend aan een meetdag is de $\mathrm{CO}_{2}$ productie van het strobed bepaald door in minimaal 1 hok op 3 verschillende plekken van het strobed het $\mathrm{CO}_{2}$-concentratieverloop gedurende ca. 10 minuten te meten. Een meetplek is 1 $\mathrm{m}^{2}$ groot en wordt gemarkeerd door een frame enkele centimeters in het bed te plaatsen. Op het frame wordt een zgn Lindvall-box geplaatst waarin een luchtstroom wordt rondgepompt. Een ventilator zuigt de lucht vanuit de box aan en deze lucht wordt via een buis weer in de box geduwd. Hiermee ontstaat een gesloten systeem waarin de concentratie van $\mathrm{CO}_{2}$ gedurende de meettijd toe zal nemen. De concentratie in deze luchtstroom wordt gemeten met de Innova Multigasmonitor (LumaSense Technologies GmbH, Frankfurt). Het principe van deze meetmethode is gebaseerd op het effect van infrarood licht op gassen. Als een gas wordt blootgesteld aan infrarood licht met een golflengte die dat gas absorbeert zal een deel van het licht worden geabsorbeerd. Als gevolg hiervan krijgt een aantal moleculen een hoger energieniveau wat leidt tot een stijging van temperatuur en druk. Valt het infrarood licht weg dan zullen de moleculen weer terugvallen naar hun oorspronkelijke energieniveau, met als gevolg dat de temperatuur en de druk weer zullen dalen. Wanneer een gas pulserend wordt belicht ontstaat een steeds wisselende druk die resulteert in een geluidsgolf die met behulp van microfoons kan worden gedetecteerd. De concentratie van het gas in een monster wordt dan door de sterkte van het signaal bepaald. Per meetplek is minimaal 3 maal 3 minuten gemeten. Op basis van het verloop per meetplek is per meetplek een $\mathrm{CO}_{2}$ emissie (productie) per dag berekend. Door het gemiddelde van de meetplekken te vermenigvuldigen met de oppervlakte van het gehele strobed wordt de totale $\mathrm{CO}_{2}$ productie per dag verkregen.

\section{- Fijnstofconcentratie (PM10).}

Voor de meting van fijnstof is gebruik gemaakt van de DustTrack (TM Aerosol Monitor, model 8520, TSI Incorporated, Shoreview, USA). Met dit apparaat worden de deeltjes continu optisch gemeten. De gemeten deeltjes zijn kleiner dan $10 \mu \mathrm{m}$ (PM10). Deze continue metingen maakt gebruik van een lichtverstrooiingstechniek. De PM10 concentratie werd elke seconde gemeten, minuutgemiddelden werden gelogd in het geheugen van het apparaat en na de metingen gedownload met behulp van de bijbehorende software. De fijnstofconcentratie van de ingaande lucht is kortdurende gemeten, aangezien deze in het algemeen vrijwel te verwaarlozen is.

- Temperatuur/ RV. De temperatuur en RV van de (uitgaande) stallucht zijn continu gemeten en gelogd met behulp van een Escort T/RV sensor (nauwkeurigheid temperatuur: $\pm 0,35^{\circ} \mathrm{C}$ van -40 ${ }^{\circ} \mathrm{C}$ tot $0^{\circ} \mathrm{C}, \pm 0,25^{\circ} \mathrm{C}$ van $0^{\circ} \mathrm{C}$ tot $+70^{\circ} \mathrm{C}$; nauwkeurigheid $\mathrm{RV}: \pm 3 \%$ ).

In Bijlage 1 is een beschrijving gegeven van de verschillende meetlocaties en is aangegeven waar in de stal is gemeten. Het is belangrijk dat tijdens de metingen de inkomende lucht in de te bemeten stal zo min mogelijk bevuild is met vervuilende componenten die geëmitteerd zijn uit nabijgelegen stallen. De stallen hebben daardoor ieder een bepaalde windrichting waarbij bij voorkeur wordt gemeten. Deze voorkeurs windrichting is voor elke locatie vermeld. Per locatie en per windrichting wordt bepaald wat de locatie wordt voor de concentratiemetingen van de ingaande lucht. Zo mogelijk wordt dit meetpunt op tenminste $10 \mathrm{~m}$ van de stal geplaatst.

Naast deze metingen zijn tijdens bovengenoemde meetdagen, de volgende waarnemingen gedaan:

- Het bevuilde vloeroppervlak. Op een rastertekening van de stal werd het met urine bevuilde oppervlak van de mestruimte en van de ligruimte vastgelegd. Vervolgens werd in vertaald in een percentage bevuiling $0 \%$ is schoon en $100 \%$ is volledig bevuild.

- Reinheid van het strobed scoren: Ook hier wordt een score van 0 tot $100 \%$ gehandteerd waarbij $0 \%$ volledig schoon strooisel is en bij $100 \%$ het strooisel zeer vuil en vochtig is.

- Luchtsnelheid, temperatuur en stroming ingaande lucht. Bij de tweede meting werd de luchtsnelheid van de ingaande stallucht aan beide zijden van de stal op 5 plekken, verspreid over 
de lengte van de stal, gemeten. Dit werd uitgevoerd met een kleine vleugelrad anemometer van Testo.

- Strobed. De gemiddelde laagdikte van het stro op de helling werd bepaald, waarbij met bovenin wordt bedoeld achter in het hok, de plek waar het stro wordt ingestrooid. Tevens werd de strotemperatuur gemeten in het midden van het strobed.

Tijdens iedere meting is het volgende geregistreerd:

- Aantal dieren.

- Het gemiddeld geschat gewicht van de dieren.

- De gemiddeld geschatte groei van de dieren.

- De gemiddelde ruwvoeropname van de dieren (in $\mathrm{kg} \mathrm{ds/dag).}$

- De gemiddelde krachtvoeropname van de dieren (in $\mathrm{kg} \mathrm{ds/dag).}$

- $\quad$ Stalbezetting: aantal aanwezige dieren ten opzichte van het aantal beschikbare dierplaatsen.

- Frequentie van schuiven en moment laatste keer schuiven.

- Het rantsoen: hoeveelheden van de verschillende grondstoffen per dier per dag.

- De gezondheidstoestand van de dieren op dat moment.

- Eventuele bijzonderheden.

\subsubsection{Data analyse}

Het ventilatiedebiet is bepaald met de zogenaamde $\mathrm{CO}_{2}$-balans methode. De stallen werden natuurlijk geventileerd met gedeeltelijk open zijwanden voor luchtinlaat die met ventilatiedoek geregeld kon worden en een open nok die diende als luchtuitlaat. Voor bepaling van het ventilatiedebiet is uitgegaan van het natuurlijk aanwezige tracergas $\mathrm{CO}_{2}$. De productie van $\mathrm{CO}_{2}$ door de aanwezige dieren werd berekend aan de hand van de $\mathrm{ClGR}$ rekenregels voor vleesvee. Er is daarnaast rekening gehouden met de $\mathrm{CO}_{2}$-productie uit het strobed in de stallen.

Het totale ventilatiedebiet in stal i op dag j werd berekend door de totale $\mathrm{CO}_{2}$-productie van de dieren op te tellen bij de $\mathrm{CO}_{2}$-productie uit het strobed en dit te delen door het verschil tussen uitgaande en ingaande $\mathrm{CO}_{2}$-concentratie:

$V_{i j}=\left(\mathrm{CO}_{2} \operatorname{prod}_{\text {dieren }_{i j}}+\mathrm{CO}_{2} \operatorname{prod}_{\text {stro }_{i j}}\right) /\left(\mathrm{CO}_{2} \mathrm{uit}_{i j}-\mathrm{CO}_{2_{i n_{i j}}}\right)$

Waarin: $\mathrm{CO}_{2}$-prod_dieren ${ }_{\mathrm{ij}}$ en $\mathrm{CO}_{2}$-prod_stroij $z$ zijn weergegeven in $\mathrm{m}^{3} /$ uur en $\mathrm{CO}_{2}$-uitij en $\mathrm{CO}_{2}$-in $n_{\mathrm{ij}}$ in $\mathrm{m}^{3} / \mathrm{m}^{3}$.

De $\mathrm{CO}_{2}$-productie van de dieren werd met de volgende formule berekend:

$\mathrm{CO}_{2}$ prod $_{\text {dieren }_{i j}}=$ Warmteprod $_{\text {dier }_{i j}} \times 0,192 \times$ aantal_dieren $_{i j}$

Waarin: Warmteprod_dierij is de warmteproductie per aanwezig dier $(\mathrm{kW}) ; 0,192$ is de $\mathrm{CO}_{2}$-productie in $\mathrm{m}^{3} / \mathrm{h}$ per kW (Liu et al., 2016), dit is inclusief de $\mathrm{CO}_{2}$-productie uit de verse mest; aantal_dieren ij is het aantal dieren in stal i op dag j

De warmteproductie (kW) per dier kan als volgt worden berekend:

Warmteprod $_{\text {dier }_{i j}}=\left\{7,64 \times M^{0,69}+G \times\left[\frac{23}{E_{\text {voer }}}-1\right]\left[\frac{57,27+0,302 \times M}{1-0,171 \times G}\right]\right\} \times 10^{-3}$

Waarin: $M$ is gemiddeld diergewicht $(\mathrm{kg}) ; \mathrm{G}$ is de gemiddelde dagelijkse groei $(\mathrm{g} / \mathrm{d})$; Ever $_{\text {vor }}$ is het energiegehalte van het voer ( $\mathrm{MJ} / \mathrm{kg} \mathrm{ds}$ ) voor ruwvoer is dit $10 \mathrm{MJ} / \mathrm{kg}$ ds en voor $\mathrm{krachtvoer} 11-12 \mathrm{MJ} / \mathrm{kg} \mathrm{ds}$ (CIGR, 2002).

De $\mathrm{CO}_{2}$-productie uit het strobed werd bepaald met behulp van een zogenaamde statische fluxkamer. Per meetplek werden minimaal 3 metingen uitgevoerd en uit de toename van de CO2-concentratie in de fluxkamer kon de emissie per $\mathrm{m}^{2}$ strobed worden berekend. Door dit getal vervolgens te vermenigvuldigen met de totale oppervlakte van het strobed in de stal kon de totale $\mathrm{CO}_{2}$-productie uit het strobed worden bepaald ( $\mathrm{CO}_{2}$ prod_stroij). 
De emissies werden per stal $(i=1,2,3,4)$ berekend door per meetdag $(j=1,2)$ de emissies van ammoniak, fijnstof en broeikasgassen te berekenen op basis van het 24-uurs gemiddelde ventilatiedebiet $\left(V_{i j}\right)$ en de 24-uurs gemiddelde concentraties van de uitgaande lucht ( $C_{-}$uitij) en de ingaande lucht $\left(C_{-}\right.$in $\left._{\text {ij }}\right)$ :

$E_{i j}=V_{i j} \times\left(C_{u i t_{i j}}-C_{i n_{i j}}\right)$

Waarin: $E_{i j}$ is weergegeven in $\mathrm{mg} / \mathrm{uur}, \mathrm{V}_{\mathrm{ij}}$ in $\mathrm{m}^{3} / \mathrm{uur}$ en $\mathrm{C}_{-}$uit $\mathrm{t}_{\mathrm{ij}}$ en $\mathrm{C}_{-} \mathrm{in}_{\mathrm{ij}}$ in $\mathrm{mg} / \mathrm{m}^{3}$. Voor omrekening van ammoniakconcentratie in ppm naar $\mathrm{mg} / \mathrm{m}^{3}$ gebruiken we de conversiefactor $17 / 24$ (17 is molair gewicht van ammoniak $(\mathrm{g} / \mathrm{mol})$ en 24 is het molair volume van een gas $(\mathrm{L} / \mathrm{mol})$ bij $20^{\circ} \mathrm{C}$.

De emissie per dier is berekend door de emissie uit de totale stal te delen door het aantal dieren wat normaal gesproken bij dit systeem, bij volledige bezetting, in de stal zit. Deze emissie is vervolgens omgerekend naar $\mathrm{kg} / \mathrm{jaar}$ per dierplaats door de berekende emissie in $\mathrm{mg} / \mathrm{uur}$ per dier te vermenigvuldigen met ( $24 \times 365 \times$ leegstandsfactor) / 106. De leegstandsfactor voor vleesvee is 1,0 (Groenestein \& Aarnink, 2008), dus er wordt vanuit gegaan dat de stal steeds volledig bezet is. In het onderzoek is geverifieerd in hoeverre dit werkelijk het geval is. 


\section{Resultaten}

\subsection{Metingen}

In tabel 2 worden de bedrijfsgegevens gepresenteerd waaronder de metingen zijn uitgevoerd. In tabel 3 en 4 worden de resultaten van de 2 uitgevoerde metingen binnen in de stal gegeven en tabel 5 geeft de resultaten van de metingen buiten de stal (ingaande lucht). In tabel 6 worden de resultaten van de $\mathrm{CO}_{2}$-productie metingen uit het strobed gegeven.

Uit tabel 2 is op te maken dat de stallen tijdens de metingen vrijwel volledig bezet waren, behalve stal 1 die een duidelijk lager bezettingspercentage had. Uit tabel 3 blijkt dat de mestgang vrijwel volledig bevuild is met mest en urine gedurende alle metingen in alle stallen. De ligruimte is voor ca. 1/5 deel bevuild met mest en urine. De hoeveelheid stro is bij de mestgang wat geringer dan in het midden en boven in de hokken. De temperatuur van het strobed is duidelijk hoger dan de gemiddelde temperatuur van de uitgaande stallucht $\left(23,3\right.$ vs. $\left.9,6^{\circ} \mathrm{C}\right)$. Uit tabel 4 blijkt dat de gemeten concentraties ammoniak in de uitgaande stallucht relatief laag zijn. De 24-uurs gemiddelde concentraties varieerden tussen 0,9 en 5,7 ppm, met een gemiddelde van 2,1 ppm. De gemiddelde concentraties $\mathrm{CO}_{2}, \mathrm{CH}_{4}$ en $\mathrm{N}_{2} \mathrm{O}$ in de uitgaande stallucht waren respectievelijk 574, 13,1 en 0,44 ppm. De gemiddelde concentratie PM10 in de uitgaande stallucht was $0,078 \mathrm{mg} / \mathrm{m}^{3}$. De RV in de uitgaande stallucht was gemiddeld $90,9 \%$. De gemiddelde concentratie $\mathrm{NH}_{3}$ in de ingaande lucht was laag $(0,05$ ppm). De gemiddelde concentraties $\mathrm{CO}_{2}, \mathrm{CH}_{4}$ en $\mathrm{N}_{2} \mathrm{O}$ in de ingaande stallucht waren respectievelijk 436, 2,1 en 0,42 ppm (tabel 5). De gemiddelde concentratie PM10 in de ingaande stallucht was 0,053 $\mathrm{mg} / \mathrm{m}^{3}$. De $\mathrm{T}$ en $\mathrm{RV}$ in de ingaande stallucht waren gemiddeld respectievelijk $9,1^{\circ} \mathrm{C}$ en $90,5 \%$. Het verschil tussen uitgaande en ingaande $\mathrm{CO}_{2}$-concentratie varieerde (gemiddeld over 24 uur) tussen de verschillende metingen van 26 tot $304 \mathrm{ppm}$. De $\mathrm{CO}_{2}$-productie uit het strobed (tabel 6) varieerde tussen 3,6 en 16,8 g/(uur. $\left.\mathrm{m}^{2}\right)$ met een gemiddelde van $8,9 \mathrm{~g} /\left(\right.$ uur. $\left.\mathrm{m}^{2}\right)$.

Tabel 2 Stal- en diergegevens per meting per stal (in bijlage 2 is de samenstelling van het rantsoen per locatie opgenomen).

\begin{tabular}{|c|c|c|c|c|c|c|c|c|}
\hline & \multicolumn{2}{|l|}{ Stal 1} & \multicolumn{2}{|l|}{ Stal 2} & \multicolumn{2}{|l|}{ Stal 3} & \multicolumn{2}{|l|}{ Stal 4} \\
\hline & Meting 1 & Meting 2 & Meting 1 & Meting 2 & Meting 1 & Meting 2 & Meting 1 & Meting 2 \\
\hline Datum start meting & 3-10-‘16 & $19-12-‘ 16$ & 28-9-‘16 & 21-12-‘16 & 15-11-‘16 & $12-12-‘ 16$ & $10-1-‘ 17$ & 11-1-‘17 \\
\hline Aantal dieren in de stal & 165 & 140 & 137 & 134 & 197 & 204 & 192 & 192 \\
\hline Stalbezetting (\%) & 87 & 74 & 98 & 96 & 97 & 100 & 98 & 98 \\
\hline Geschat gewicht dieren $(\mathrm{kg})$ & 700 & 700 & 725 & 725 & 550 & 590 & 560 & 560 \\
\hline Geschatte groei per dier (g/d) & 1700 & 1700 & 1400 & 1400 & 1700 & 1500 & 1500 & 1500 \\
\hline $\begin{array}{l}\text { Aantal dagen na laatste } \\
\text { mestafvoer mestgang }\end{array}$ & 4 & 4 & 3 & 4 & 4 & 2 & 1 & 1 \\
\hline $\begin{array}{l}\text { Hoeveelheid ruwvoer / dier } \\
\text { (kg ds / dag) }\end{array}$ & 8,1 & 8,1 & 6,6 & 5,6 & 7,4 & 7,4 & 6,4 & 6,4 \\
\hline $\begin{array}{l}\text { Hoeveelheid krachtvoer/dier } \\
\text { (kg ds/dag) }\end{array}$ & 2,3 & 2,3 & 5,0 & 3,8 & 2,5 & 2,5 & 2,7 & 2,7 \\
\hline Samenstelling rantsoen & gemengd & gemengd & gemengd & gemengd & gemengd & gemengd & gemengd & gemengd \\
\hline Gezondheidstoestand dieren & goed & goed & goed & goed & goed & goed & goed & goed \\
\hline
\end{tabular}


Tabel 3 Gegevens over de toestand van de mestgang en het strobed tijdens de metingen per stal.

\begin{tabular}{|c|c|c|c|c|c|c|c|c|}
\hline & \multicolumn{2}{|l|}{ Stal 1} & \multicolumn{2}{|l|}{ Stal 2} & \multicolumn{2}{|l|}{ Stal 3} & \multicolumn{2}{|l|}{ Stal 4} \\
\hline & Meting 1 & Meting 2 & Meting 1 & Meting 2 & Meting 1 & Meting 2 & Meting 1 & Meting 2 \\
\hline Datum start meting & 4-10-'16 & $20-12-{ }^{\prime} 16$ & 29-9-`16 & $21-12-‘ 16$ & 16-11-'16 & $19-12-{ }^{\prime} 16$ & 23-12-‘16 & 11-1-'17 \\
\hline \multicolumn{9}{|l|}{ Bevuild vloeroppervlak: } \\
\hline - Mestgang (dichte vloer) & $100 \%$ & $100 \%$ & $100 \%$ & $100 \%$ & $100 \%$ & $100 \%$ & $100 \%$ & $100 \%$ \\
\hline - $\quad$ Midden & 18,1 & 18,0 & 15,0 & 8,5 & 14,0 & 9,0 & 25,0 & - \\
\hline - $\quad$ Bovenin & 17,5 & 23,5 & 20,0 & 10,5 & 11,5 & 21,5 & 30,0 & - \\
\hline Temperatuur strobed $\left({ }^{\circ} \mathrm{C}\right)$ & - & 23,8 & - & 19,5 & - & 25,1 & 24,3 & - \\
\hline
\end{tabular}

- Geen meting

Tabel $4 \mathrm{NH}, \mathrm{CO}_{2}$, broeikasgas en PM10 concentraties en T/RV gemeten in de stal (uitgaande stallucht).

\begin{tabular}{|c|c|c|c|c|c|c|c|c|}
\hline & \multicolumn{2}{|l|}{ Stal 1} & \multicolumn{2}{|l|}{ Stal 2} & \multicolumn{2}{|l|}{ Stal 3} & \multicolumn{2}{|l|}{ Stal 4} \\
\hline Datum start meting & 3-10-'16 & 19-12-`16 & 28-9-‘16 & $21-12-` 16$ & 15-11-‘16 & 13-12-‘16 & 10-1-'16 & $11-1-' 16$ \\
\hline $\mathrm{NH}_{3}$ concentratie (ppm) & 1,0 & 3,2 & 1,4 & 5,7 & 0,9 & 2,0 & 1,6 & 1,1 \\
\hline $\mathrm{CO}_{2}$ concentratie $(\mathrm{ppm})$ & 448 & 653 & 543 & 731 & 475 & 582 & 649 & 507 \\
\hline $\begin{array}{l}\text { Fijn stof concentratie } \\
\left(\mathrm{PM} 10, \mathrm{mg} / \mathrm{m}^{3}\right)\end{array}$ & - & 0,08 & 0,04 & - & $0,17^{1)}$ & - & 0,02 & - \\
\hline Temperatuur $\left({ }^{\circ} \mathrm{C}\right)$ & 15,0 & 5,9 & 19,6 & 7,5 & 6,2 & 8,6 & 6,4 & 7,2 \\
\hline
\end{tabular}

1) meting van 1 uur

- geen meting

Tabel $5 \quad \mathrm{NH}_{3}, \mathrm{CO}_{2}$, broeikasgas en PM10 concentraties en T/RV gemeten buiten de stal (inkomende stallucht).

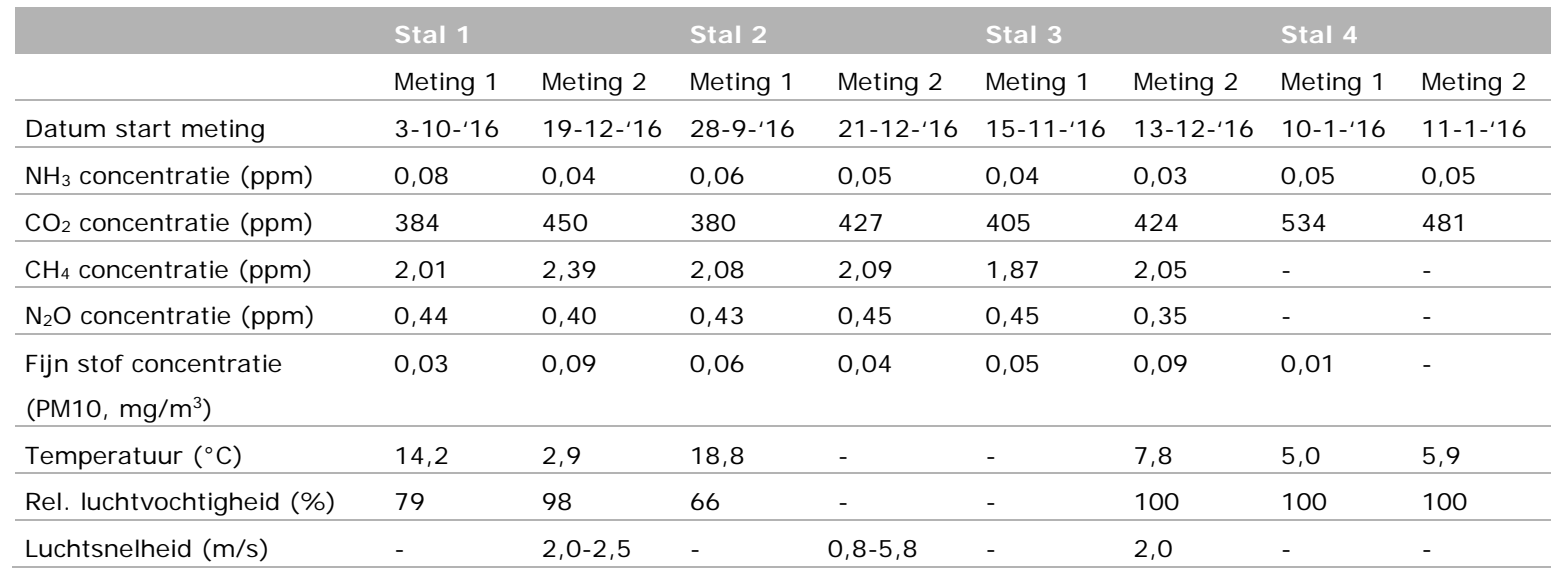

- Geen meting 
Tabel $6 \quad \mathrm{CO}_{2}$-productie in het strobed, in bijlage 2 is de informatie per meetpunt opgenomen.

\begin{tabular}{|c|c|c|c|c|c|c|c|}
\hline & \multicolumn{2}{|l|}{ Stal 1} & \multicolumn{2}{|l|}{ Stal 2} & \multicolumn{2}{|l|}{ Stal 3} & $\begin{array}{c}\text { Stal } 4 \\
\text { Meting } 1 \text { en } 2\end{array}$ \\
\hline \multirow[t]{2}{*}{ Datum start meting } & 4-10-‘16 & $20-12-{ }^{\prime} 16$ & 28-9-‘16 & $12-12-' 16$ & 15-11-‘16 & 13-12-‘16 & 23-12-'16 / \\
\hline & & & & & & & 11-01-'17 \\
\hline Aantal metingen & 5 & 8 & 5 & 8 & 6 & 6 & 8 \\
\hline
\end{tabular}

\subsection{Ventilatie en emissies}

In tabel 7 worden de $\mathrm{CO}_{2}$-producties van dieren en strobed, het berekende ventilatiedebiet en de ammoniakemissie tijdens de verschillende meetdagen in de 4 stallen gegeven. Hieruit blijkt dat de $\mathrm{CO}_{2}$-productie van het strobed relatief gering is ten opzichte van de productie door de dieren (gemiddeld 8,5\%). Het berekende ventilatiedebiet was gemiddeld $2390 \mathrm{~m}^{3} / \mathrm{uur}$ per vleesstier. De ammoniakemissie varieerde tussen de verschillende metingen van 12,7 tot 29,6 kg/jaar per dierplaats, met een gemiddelde van 21,4 . Gemiddeld waren de ammoniakemissies van de verschillende bedrijven redelijk vergelijkbaar. De gemiddelde methaanemissie was $111 \mathrm{~kg} / \mathrm{jaar}$ per dierplaats. Lachgas- en PM10-emissies konden niet nauwkeurig worden bepaald, omdat de concentraties in de uitgaande lucht vrijwel niet verhoogd waren ten opzichte van de concentraties in de ingaande lucht. In enkele gevallen werd er zelfs een negatieve emissie berekend. Dit betekent wel dat deze emissies laag zijn.

Tabel $7 \quad \mathrm{CO}_{2}$-producties van dieren en strobed, ventilatiedebiet en ammoniakemissie tijdens de verschillende metingen in de 4 stallen.

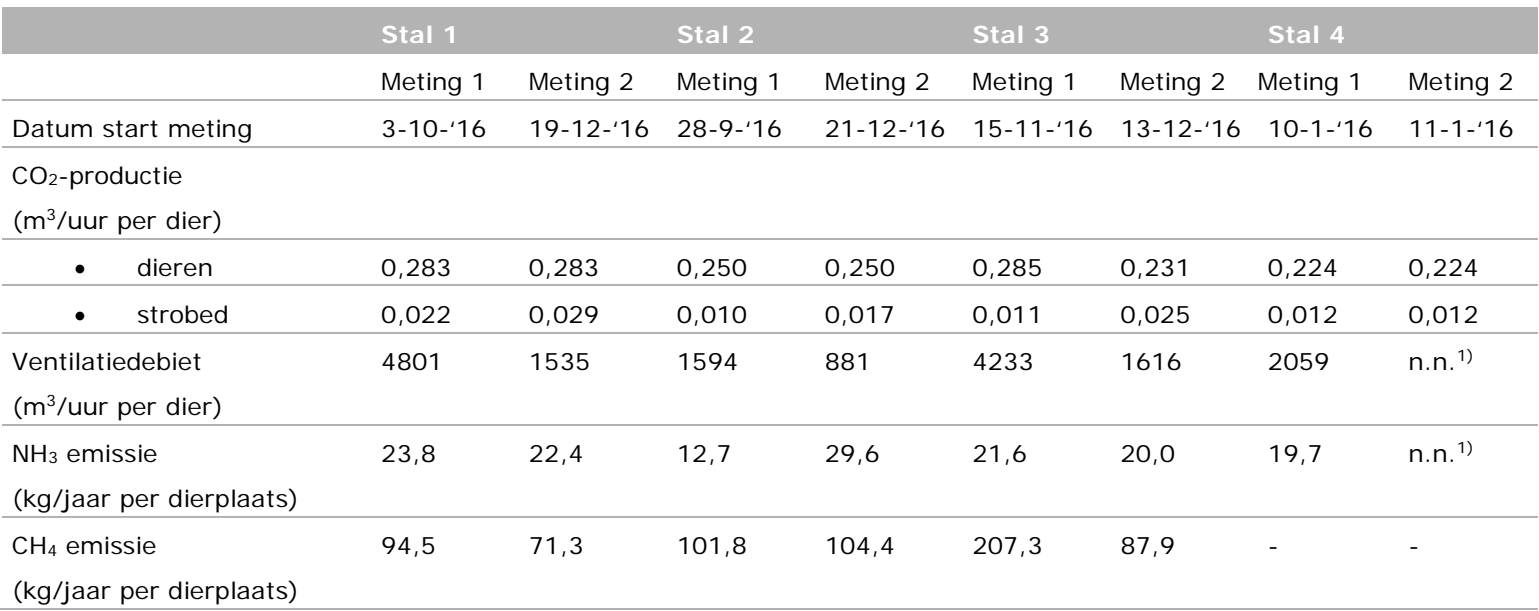

1) Niet nauwkeurig vast te stellen door klein verschil tussen uit- en ingaande $\mathrm{CO}_{2}$-concentratie.

- geen meting 


\section{$4 \quad$ Discussie}

In dit onderzoek is de $\mathrm{CO}_{2}$-balans methode toegepast om de ventilatiehoeveelheid in de stal te bepalen. Deze methode wordt regelmatig toegepast voor natuurlijk geventileerde stallen. In een onderzoek van Mosquera e.a. (2012) bij varkens- en pluimveestallen is gebleken dat deze methode voldoende betrouwbaar is om het ventilatiedebiet mee te bepalen. In het hiervoor genoemde onderzoek is een vergelijking gemaakt tussen de $\mathrm{CO}_{2}$-balans methode en een meting met een meetventilator (referentiemethode). Deze vergelijking is voor vleesstieren (nog) niet gemaakt en daardoor is niet precies aan te geven hoe betrouwbaar deze methode is voor deze diercategorie. De verwachting is echter niet dat hiermee een grote fout wordt gemaakt. Wel was in dit onderzoek het verschil in $\mathrm{CO}_{2}$-concentratie tussen uitgaande en ingaande lucht relatief laag. Dit varieerde van 26 tot 304 ppm, met een gemiddelde van 138 ppm. Door dit geringe verschil wordt de bepaling van het ventilatiedebiet minder nauwkeurig. Liu et al. (Liu et al., 2016) geven aan dat tussen uit- en ingaande $\mathrm{CO}_{2}$-concentratie een minimaal verschil vereist is van $200 \mathrm{ppm}$ om een voldoende betrouwbaar ventilatiedebiet te kunnen bepalen. Bij onze metingen was dit slechts in 2 van de 7 metingen het geval. De nauwkeurigheid van de individuele metingen neemt daardoor af. Er is echter geen aanleiding om te verwachten dat dit tot een systematische afwijking leidt. Derhalve doet dit niets af aan de conclusie dat de ammoniakemissie in deze stallen erg hoog is. Dit blijkt ook uit het feit dat de ammoniakemissie bij de 2 metingen die wel voldeden aan de eis van een minimaal verschil van 200 ppm beiden ook boven de $20 \mathrm{~kg} / \mathrm{jaar}$ per dierplaats lagen. Eén meting hebben we vanwege het zeer kleine verschil in $\mathrm{CO}_{2}$-concentratie (26 ppm verschil) niet meegenomen in de berekeningen van gemiddelde ammoniakemissie. De variatie in het berekende ventilatiedebiet op basis van de $\mathrm{CO}_{2}-$ balans methode is vrij groot, zowel binnen als tussen bedrijven. Dit zal vooral te maken hebben met de buitenomstandigheden (veel/weinig wind) en met de grootte van de inlaatopeningen. De verkennende luchtsnelheidsmetingen die zijn uitgevoerd weerspreken de relatief hoge ventilatiedebieten niet.

De uitgevoerde metingen voldoen aan de vereisten van het meetprotocol voor het vaststellen van een emissiefactor, maar door het vroegtijdig beëindigen van het onderzoek, is het aantal metingen onvoldoende om een emissiefactor vast te mogen stellen. De huidige generieke emissiefactor voor vleesstieren van 8 tot 24 maanden oud voor de roodvleesproductie bedraagt 5,3 $\mathrm{kg} \mathrm{NH}$ per dierplaats per jaar. Metingen aan een natuurlijk geventileerde vleesstierenstal met volledig roostervloer en een oppervlakte van 2,6 $\mathrm{m}^{2}$ per stier lieten een ammoniakemissie zien van gemiddeld 7,2 kg/jaar per dierplaats (Scholtens \& Huis in 't Veld, 1998). De metingen, in totaal 7 valide metingen, in de 4 vleesstierenstallen in dit onderzoek laten beduidend hogere emissies zien, namelijk gemiddeld 21,4 $\mathrm{kg} / \mathrm{jaar}$ per dierplaats. De spreiding in gemeten ammoniakemissies tussen en binnen bedrijven is groot.

Eén van de oorzaken van de gevonden hoge ammoniakemissie in het huidige onderzoek is waarschijnlijk dat de oppervlakte per dier beduidend groter was $\left(6,75\right.$ vs. $\left.2,6 \mathrm{~m}^{2} / \mathrm{stier}\right)$. Een andere belangrijke oorzaak is waarschijnlijk dat veel van de urine en feces niet in het stro, maar op de dichte betonvloer van de mestgang terecht komen. De ureum in de urine wordt naar verwachting zeer snel omgezet naar ammonium door de hoge urease-activiteit van de dichte mestvloer en van de urease in de feces. Doordat de urine en feces in de mestgang op 3 van de 4 bedrijven slechts éénmaal per week door middel van een shovel met mestschuif werd afgevoerd, zal er veel ammoniak uit de urine emitteren. Op één bedrijf werd met een automatische schuif de urine en feces 4 maal per dag verwijderd. Dit blijkt ook nog onvoldoende te zijn om de ammoniakemissie te beperken. Dit wordt waarschijnlijk vooral veroorzaakt door de snelle omzetting van ureum, waardoor een belangrijk deel van de ammonium uit de urine is geëmitteerd voordat deze wordt afgevoerd. Daar komt bij dat de urine en feces op de mestgang niet volledig gemengd worden zoals gebeurt in een mestkelder. De $\mathrm{pH}$ van urine (waarin een deel van de ureum is omgezet naar ammonium) is relatief hoog ten opzichte van de pH van mengmest (Snoek, 2016). Frequenter schuiven, bijvoorbeeld elk uur, zou de ammoniakemissie enigszins kunnen verlagen, maar waarschijnlijk niet heel sterk, aangezien, zoals 
eerder gemeld, de ureum naar verwachting zeer snel wordt omgezet naar ammonium en ook snel emitteert als ammoniak door de hoge urease-activiteit en de hoge $\mathrm{pH}$.

In een onderzoek van Cole \& Todd (2009) vervluchtigde in een uitloop voor vleesstieren ('cattle feedyard') gemiddeld 44,3\% van de uitgescheiden stikstof. Als dit allemaal als $\mathrm{NH}_{3}$ is geëmitteerd komt dit neer op een ammoniakemissie van 32,4 kg per vleesstier per jaar. Alhoewel dit een heel ander huisvestingssysteem is, geeft dit wel aan dat emissies van meer dan $20 \mathrm{~kg}$ ammoniak per dierplaats per jaar, zoals in dit onderzoek, goed mogelijk zijn.

De gemiddelde methaanemissie van $111 \mathrm{~kg}$ komt goed overeen met de methaanemissie gemeten bij melkvee van $127 \mathrm{~kg} / \mathrm{jaar}$ per jaar per dierplaats (Mosquera et al., 2010). 


\section{Conclusies}

In dit onderzoek is slechts een beperkt deel van de oorspronkelijke geplande metingen uitgevoerd ( 8 van de 24), daarom kunnen geen emissiecijfers worden bepaald die voldoen aan de vereisten om een officiële emissiefactor vast te kunnen stallen voor het hellingstalsysteem voor vleesstieren. Echter, het volgende kan wel worden geconcludeerd:

- De ammoniakemissie in een hellingstal voor vleesstieren lijkt beduidend hoger te zijn dan de huidige generieke emissiefactor voor vleesstieren.

- De methaanemissie van vleesstieren lijkt vergelijkbaar te zijn met die voor melkvee.

- De emissies van lachgas en fijnstof (PM10) zijn in deze natuurlijk, ruim geventileerde stallen voor vleesstieren moeilijk nauwkeurig te bepalen door de geringe verschillen in concentratie tussen uitgaande en ingaande stallucht. Dit betekent echter wel dat de emissies van lachgas en fijnstof laag zijn. 


\section{Literatuur}

CIGR. 2002. Heat and moisture production at animal and house levels. CIGR Working Group on Climatization of Animal Houses.

Cole, N., Todd, R. 2009. Nitrogen and phosphorus balance of beef cattle feedyards. Proc. Texas Animal Manure Management Issues Conference. pp. 17-24.

Groenestein, K., Aarnink, A.J.A. 2008. Notitie over leegstand ten behoeve van het berekenen van een emissiefactor van een stal. Intern rapport 200808, Animal Science Group van Wageningen UR. Intern rapport 200808.

Liu, Z., Powers, W., Harmon, J. 2016. Estimating Ventilation Rates of Animal Houses through CO2 Balance. Transaction of the ASABE, 59(1), 321-328.

Mosquera, J., Groenestein, K., Ogink, N.W.M., Aarnink, A.J.A. 2012. EVALUATION OF THE CO2 MASS BALANCE METHOD TO CALCULATE VENTILATION RATES FROM MECHANICALLY VENTILATED LIVESTOCK BUILDINGS. International Conference of Agricultural Engineering, The Ninth International Livestock Environment Symposium (ILES IX), July 8-12, 2012, Valencia, Spain, paper C0476, Valencia, Spain. American Society of Agricultural and Biological Engineers (ASABE).

Mosquera, J., Hol, J.M.G., Huis in 't Veld, J.W.H., Gerrits, F.A., Ogink, N.W.M., Aarnink, A.J.A. 2010. Fijnstofemissie uit stallen: melkvee. Livestock Research. Rapport 296.

Scholtens, R., Huis in 't Veld, J.H.W. 1998. Praktijkonderzoek naar de ammoniakemissie van stallen XXXXI. Natuurlijk geventileerde vleesstierenstal met betonroosters. DLO-rapport 98-1005, 16.

Snoek, J.W. 2016. Refining a model-based assessment strategy to estimate the ammonia emission from floors in dairy cow houses. in: PhD thesis, Wageningen University, the Netherlands, Vol. PhD, PhD thesis, Wageningen University, the Netherlands, pp. 182. 


\section{Bijlage 1 Omschrijving meetlocaties}

Stal 1

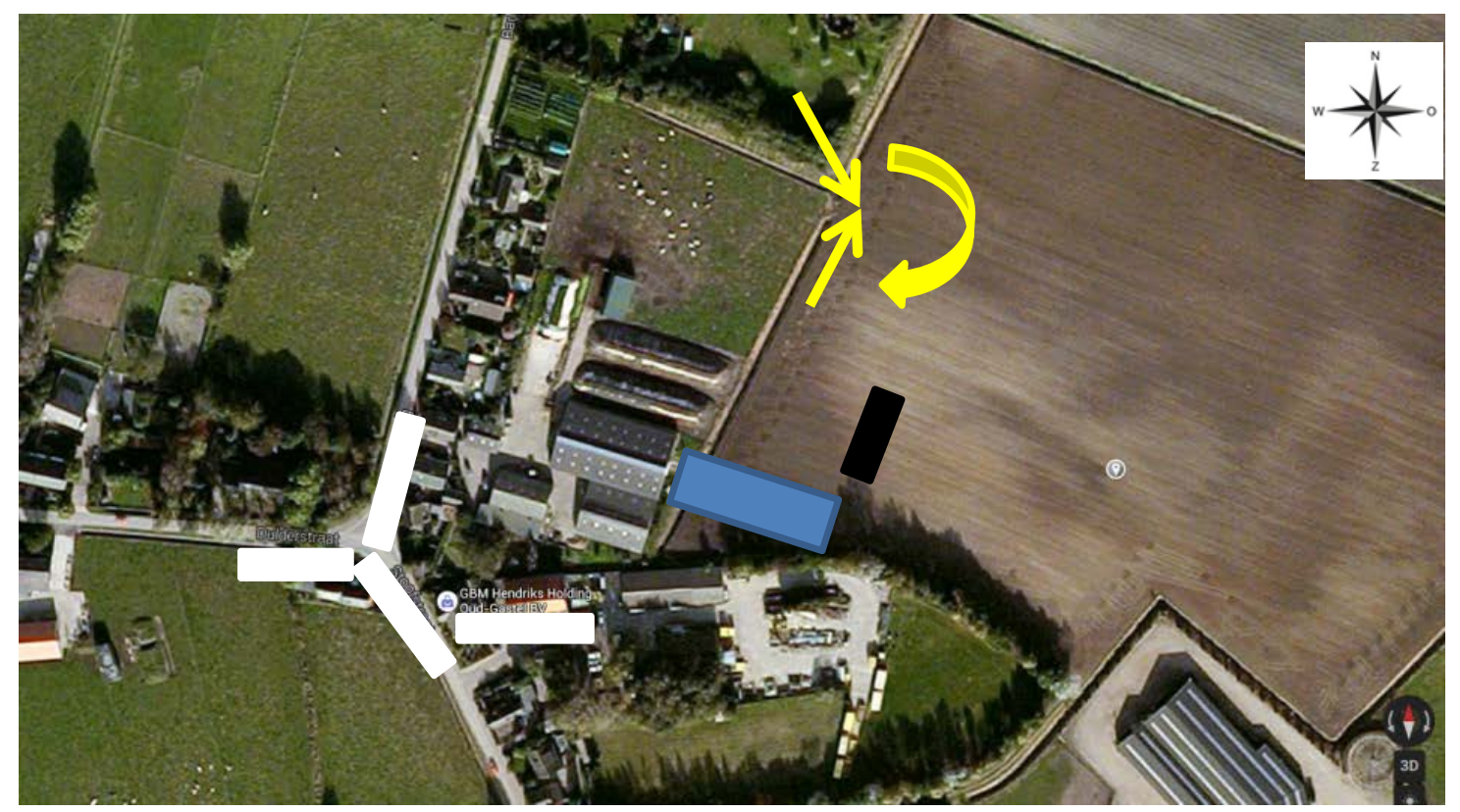

Figuur 1 Situatie stal 1. De blauwe stal is de meetstal. De gele peilen duiden op de voorkeurs windrichting tijdens de metingen (NW - ZZW).

In figuur 1 is de situatie weergegeven zoals deze op Googlemaps te vinden is. In figuur 1 zijn de stallen die recent zijn bijgebouwd toegevoegd, de blauwe stal is de meetstal, de zwarte stal is een openfront stal voor vleesstieren. Op het bedrijf dat naast het vleesstierenbedrijf ligt worden geen dieren gehouden.

De stierenstal waar de metingen worden uitgevoerd is ingericht met hokken waarin per hok een groep dieren wordt gehuisvest. Een hok bestaat uit een ingestrooid gedeelte en een dichte vloer. De stal is symmetrisch ingericht. Dit betekent aan 2 zijden een rij met hokken en in het midden een voergang. De combinatie van een ingestrooid deel (ingestrooid met stro) en dichte vloer wordt hellingstal genoemd waarbij de dieren het stro voor een deel uit de ingestrooide ruimte naar de dichte vloer lopen. Deze dichte vloer, ook wel mestgang genoemd, wordt wekelijks schoon gemaakt door middel van een shovel. Hierbij wordt de mest van de dichte vloer uit de stal verwijderd. Het instrooien van de ruimte wordt dagelijks gedaan. Hiervoor is een plafond aanwezig boven een deel van de hokken (over de hele lengte boven een deel van de ingestrooide ruimte). Op het plafond zijn strobalen geplaatst waarvan het stro wordt gebruikt voor het instrooien. De dieren worden eenmaal per dag gevoerd. De stal is natuurlijk geventileerd waarbij de inlaatopeningen aan beide lengte zijden van de stal zij aangebracht. De inlaat zit op ca $2 \mathrm{~m}$ en is ca $1 \mathrm{~m}$ hoog. De luchtinlaat wordt indien nodig beperkt door middel van een doek dat handmatig wordt bediend. De lucht gaat onder andere via de nok naar buiten. Door de aanwezigheid van strobalen in de ruimte zal de luchtbeweging in de stal worden beïnvloed. Door de metingen aan de uitgaande lucht in de buurt van de nok uit te voeren wordt ingeschat dat daar de lucht voldoende tijd heeft gehad om goed te mengen en daarmee de monstername goed kan plaats vinden. 
Tabel $1 \quad$ Praktische informatie over meetstal 1.

\begin{tabular}{ll} 
Stal afmetingen & $21 \times 78 \mathrm{~m}$ hoogte ca $10,5 \mathrm{~m}$ \\
Uitvoering & Potstal gebruikt als hellingstal \\
\hline Indeling & $\begin{array}{l}\text { Aan iedere zijde } 17 \text { hokken; middenin een voergang } 5 \mathrm{~m} \\
\text { breed }\end{array}$ \\
\hline Ventilatie & Natuurlijk \\
\hline Regelbare luchtinlaat & Handmatig \\
\hline Dierplaatsen & 190 \\
\hline Groeitraject (mnd) & Gem. 10 mnd (van ca 12 mnd tot ca 24 mnd) \\
\hline Ras & Belgisch witblauwe (kruislingen) \\
\hline Oppervlak / dier & $6,4 \mathrm{~m}^{2}$ \\
\hline Hokafmetingen & $32 \mathrm{~m}^{2}$ \\
\hline Opp strobed & $16 \mathrm{~m}^{2}$ \\
\hline Opp mestgang & $16 \mathrm{~m}^{2}$ \\
\hline Uitvoering mestgang & Dichte vloer \\
\hline Uitmestwijze & Shovel (handmatig) \\
\hline Uitmestfrequentie & $1 \times$ per week \\
\hline Instrooifrequentie & $1 \times$ per dag \\
\hline Wijze van instrooien & Handmatig \\
\hline Stroverbruik (kg/d) & 3 tot 4 kg \\
\hline Wijze \& frequentie voeren & $1 \times$ per dag \\
\hline Rantsoen & Gemengd \\
\hline Gemiddelde opname & $22 \mathrm{~kg}$ ds \\
\hline
\end{tabular}

In onderstand plattegrond en doorsnede van een stierenstal staat globaal aangegeven op welke plekken de concentraties van ingaande lucht (achtergrondconcentratie en uitgaande lucht (stalconcentratie) gemeten zal worden.

: Meetpunt achtergrondconcentraties $\mathrm{NH} 3, \mathrm{CO}_{2}, \mathrm{~N}_{2} \mathrm{O}, \mathrm{CH}_{4}$ en PM10.

: Meetpunten stalconcentratie $\mathrm{NH} 3, \mathrm{CO}_{2}, \mathrm{~N}_{2} \mathrm{O}$, en $\mathrm{CH}_{4}$.

: Meetpunt PM10 stal en buiten 


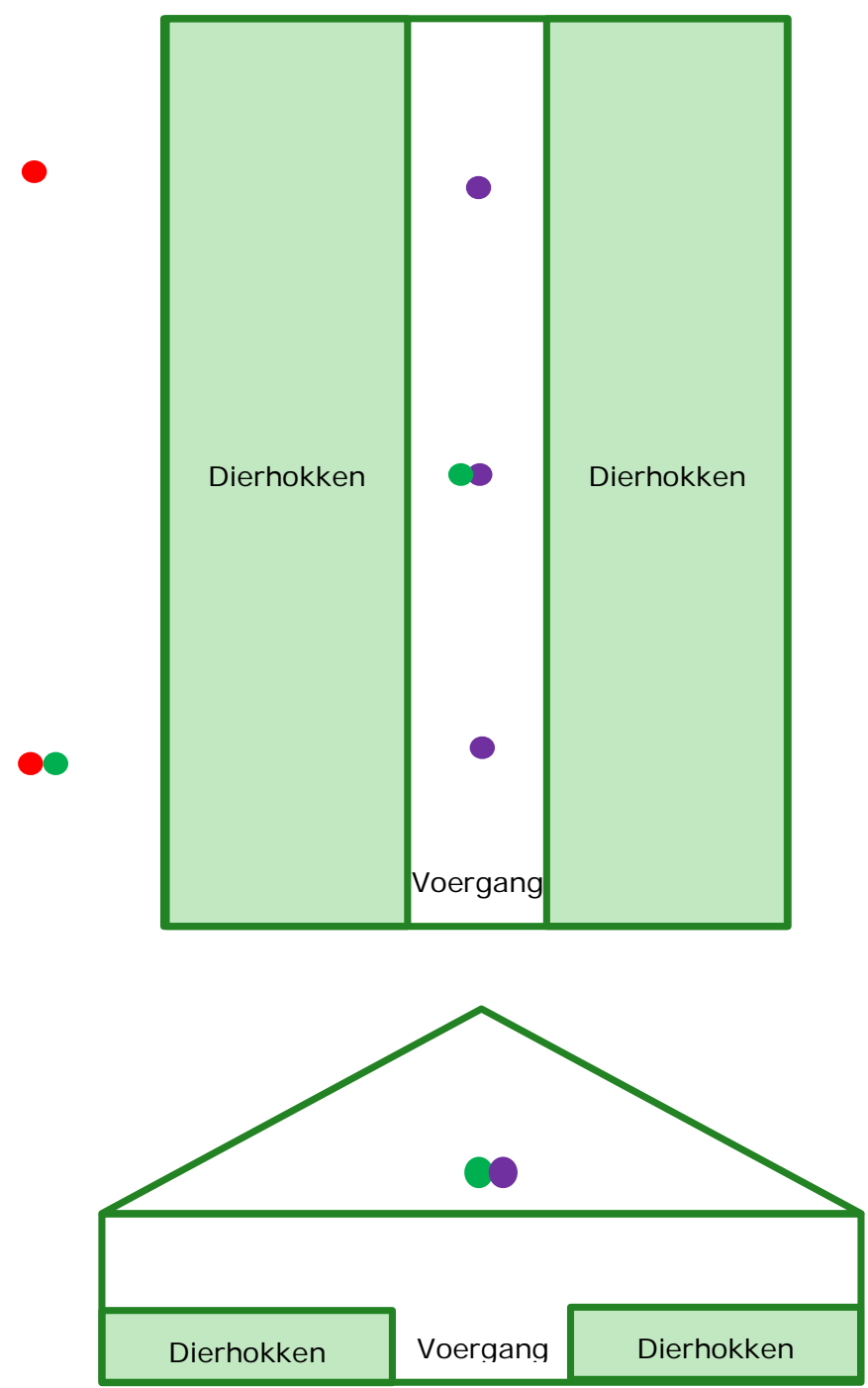




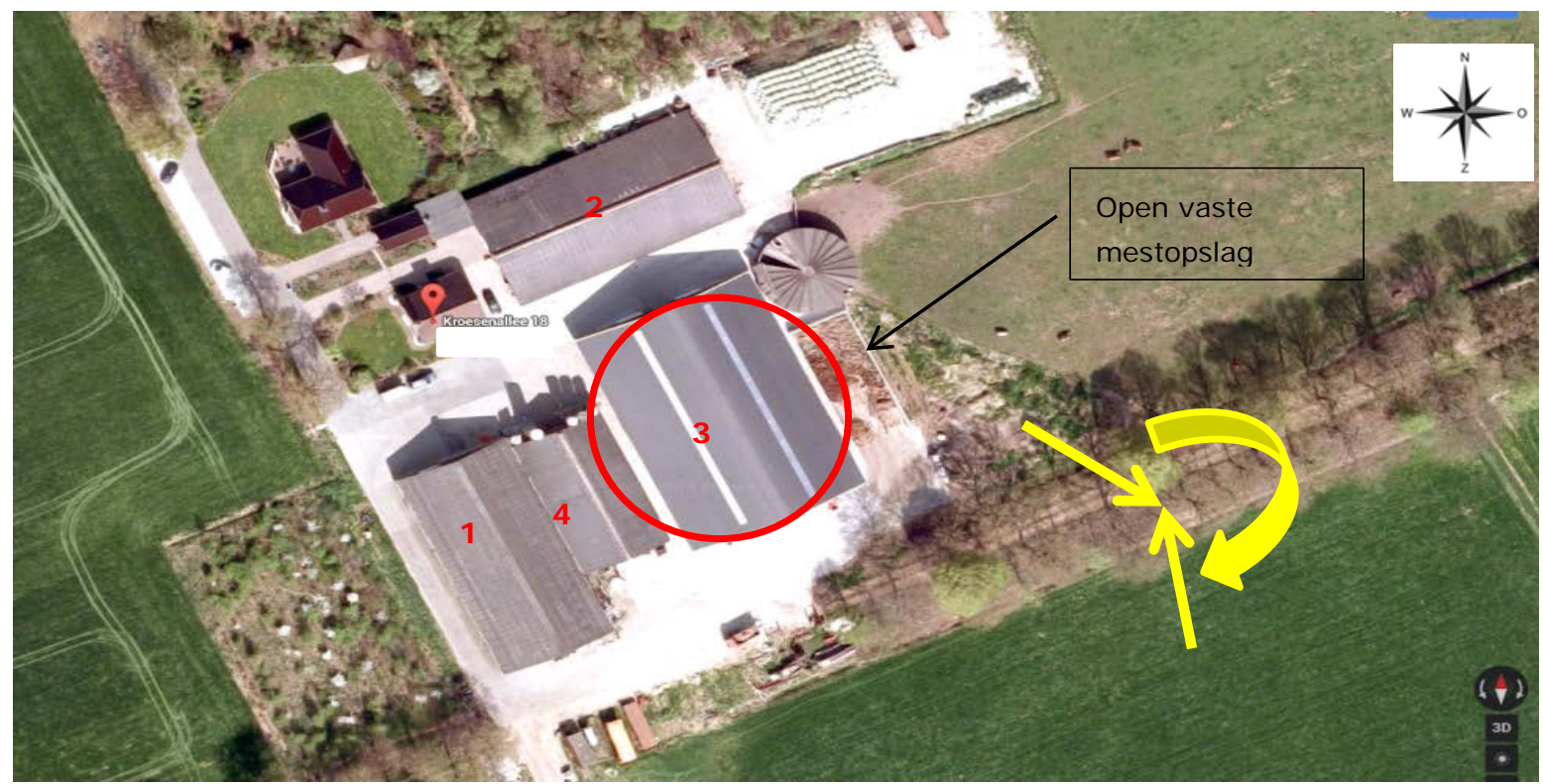

Figuur 2 Situatie stal 2 (stal met $\mathrm{nr}$. 3 op de foto). De gele peilen duiden op de voorkeurs windrichting tijdens de metingen (NW - ZZO). Als in stal 2 zoogkoeien zitten mag de wind ook niet uit die richting komen.

In figuur 2 is de situatie weergegeven zoals deze op Googlemaps te vinden is. In de figuur zijn de bedrijfsgebouwen waar zich dieren in bevinden genummerd. In gebouw nummer 1 en 3 worden vleesstieren gehouden. Waarbij nummer 3 de stal is waar de metingen zijn gedaan. Stal 2 wordt gebruikt voor de huisvesting van zoogkoeien in de winterperiode. Deze stal staat dus meestal leeg. Stal 4 wordt gebruikt als machineloods.

De stierenstal is ingericht met hokken waarin per hok een groep dieren wordt gehuisvest. Een hok bestaat uit een ingestrooid gedeelte en een dichte vloer. De stal is symmetrisch ingericht. Dit betekent aan 2 zijden een rij met hokken en in het midden een voergang. De combinatie van een ingestrooid deel (ingestrooid met stro) en dichte vloer wordt hellingstal genoemd waarbij de dieren het stro voor een deel uit de ingestrooide ruimte naar de dichte vloer lopen. Deze dichte vloer, ook wel mestgang genoemd, wordt wekelijks schoon gemaakt door middel van een shovel. Hierbij wordt de mest van de dichte vloer uit de stal verwijderd. Het instrooien van de ruimte wordt dagelijks gedaan. Hiervoor is een plafond aanwezig boven een deel van de hokken (over de hele lengte boven een deel van de ingestrooide ruimte). Op het plafond zijn strobalen geplaatst waarvan het stro wordt gebruikt voor het instrooien. De dieren worden eenmaal per dag gevoerd.

De stal is natuurlijk geventileerd waarbij de inlaatopeningen aan beide lengte zijden van de stal zij aangebracht. De inlaat zit op ca $2 \mathrm{~m}$ en is ca $1 \mathrm{~m}$ hoog. De luchtinlaat wordt indien nodig beperkt door middel van een doek dat handmatig wordt bediend. De lucht gaat onder andere via de nok naar buiten. Door de aanwezigheid van strobalen in de ruimte zal de luchtbeweging in de stal worden beïnvloed. Door de metingen aan de uitgaande lucht in de buurt van de nok uit te voeren wordt ingeschat dat daar de lucht voldoende tijd heeft gehad om goed te mengen en daarmee de monstername goed kan plaats vinden. Aan de oostzijde van de stal bevindt zich een vaste mestopslag. Deze wordt alleen in het winterseizoen gebruikt. Wanneer er een meting in deze periode plaatst vindt zal de mesthoop worden afgedekt. 
Tabel 2 Praktische informatie over meetstal 2.

\begin{tabular}{|c|c|}
\hline Stal afmetingen & $49 * 27,5 \mathrm{~m}$ \\
\hline Uitvoering & Hellingstal \\
\hline Indeling & $\begin{array}{l}\text { Aan iedere zijde } 11 \text { hokken; middenin een voergang } 5 \mathrm{~m} \\
\text { breed }\end{array}$ \\
\hline Ventilatie & Natuurlijk \\
\hline Regelbare luchtinlaat & Handmatig \\
\hline Dierplaatsen & 150 \\
\hline Groeitraject (mnd) & Gem. 10 mnd (van ca 12 mnd tot ca 24 mnd) \\
\hline Ras & Blonde d 'Aquitaine \\
\hline Oppervlak / dier & $7,2 \mathrm{~m}^{2}$ \\
\hline Hokafmetingen & $4,4 * 11,2=49,3 \mathrm{~m}^{2}$ \\
\hline Opp strobed & $4,4 * 7,1=31,2 \mathrm{~m}^{2}$ \\
\hline Opp mestgang & $4,4 * 4,4=19,4 \mathrm{~m}^{2}$ \\
\hline Uitvoering mestgang & Dichte vloer \\
\hline Uitmestwijze & Shovel met mestschuif (handmatig) \\
\hline Uitmestfrequentie & $1 x$ per 5 dagen \\
\hline Instrooifrequentie & $1 \times$ per dag \\
\hline Wijze van instrooien & Handmatig \\
\hline Stroverbruik (kg/d) & 3 tot $4 \mathrm{~kg}$ \\
\hline Wijze \& frequentie voeren & $1 \times$ per dag \\
\hline Rantsoen & Gemengd \\
\hline Gemiddelde opname & $26 \mathrm{~kg} \mathrm{ds}$ \\
\hline
\end{tabular}

In onderstand plattegrond en doorsnede van een stierenstal staat globaal aangegeven op welke plekken de concentraties van ingaande lucht (achtergrondconcentratie en uitgaande lucht (stalconcentratie) gemeten zal worden.

: Meetpunt achtergrondconcentraties $\mathrm{NH}_{3}, \mathrm{CO}_{2}, \mathrm{~N}_{2} \mathrm{O}, \mathrm{CH}_{4}$ en PM10.

: Meetpunten stalconcentratie $\mathrm{NH}_{3}, \mathrm{CO}_{2}, \mathrm{~N}_{2} \mathrm{O}$, en $\mathrm{CH}_{4}$.

: Meetpunt PM10 stal en buiten 


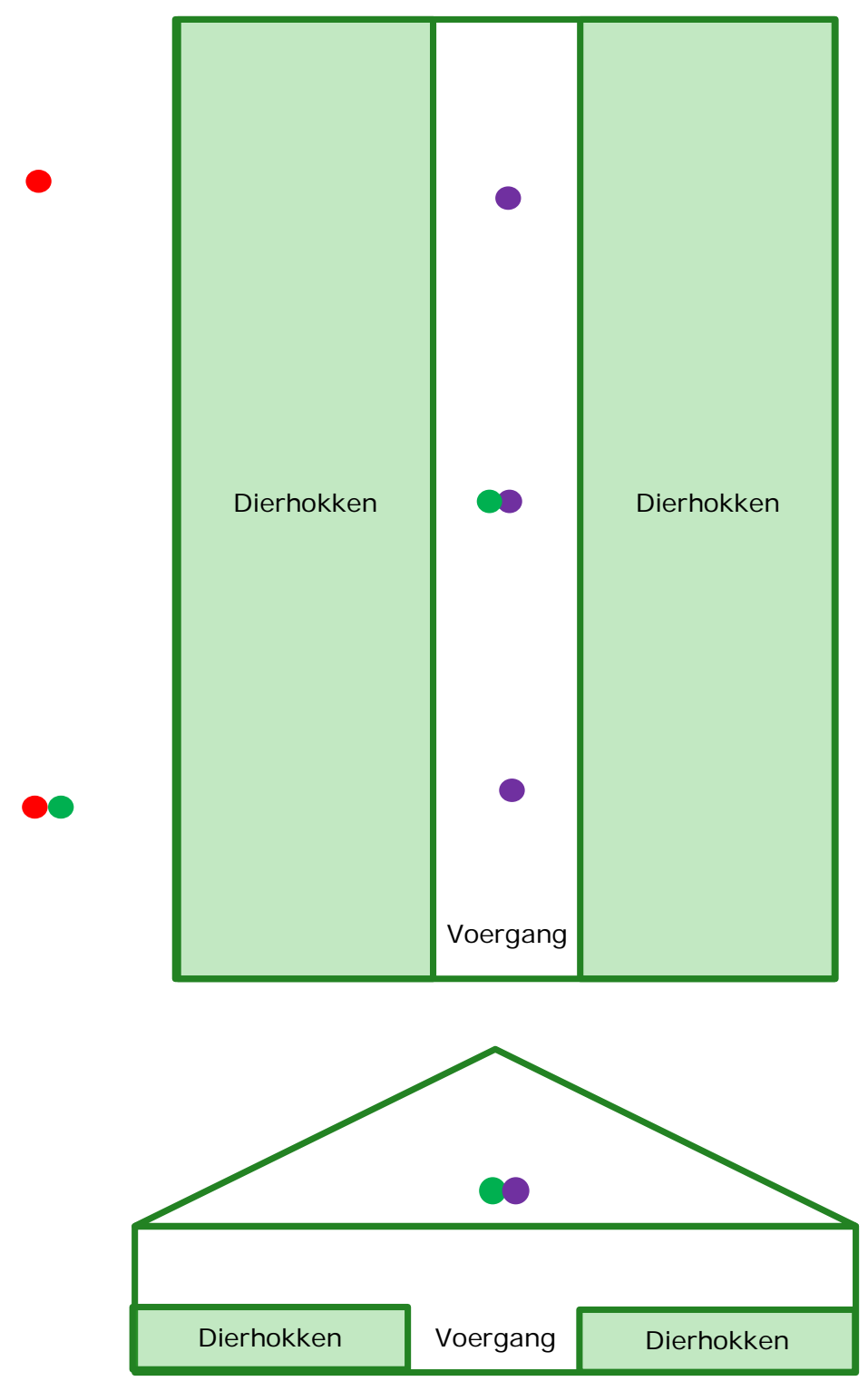




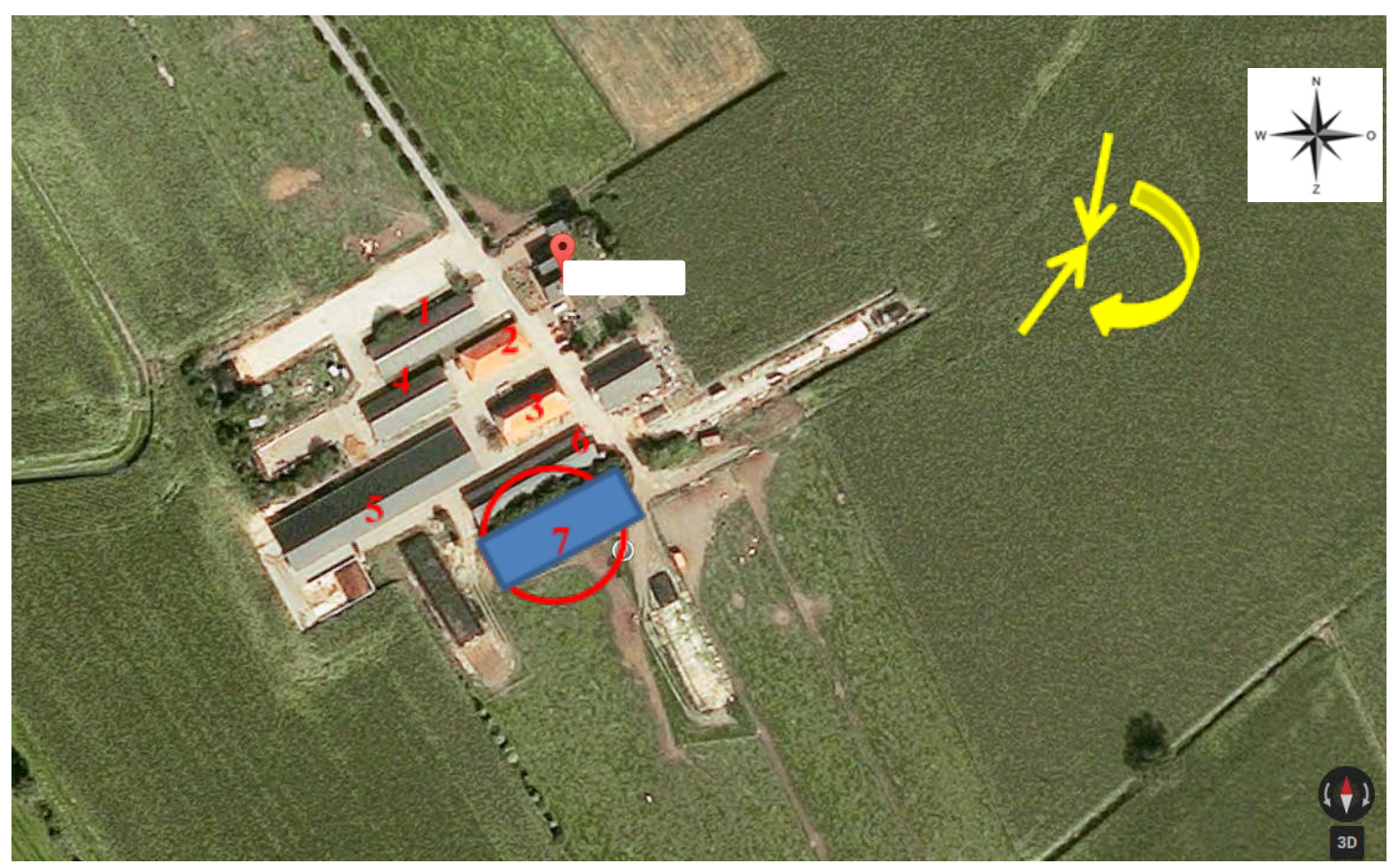

Figuur 3 Situatie stal 3. De gele peilen duiden op de voorkeurs windrichting tijdens de metingen (NNO - ZW).

In figuur 3 is de situatie weergegeven zoals deze op Googlemaps te vinden is. Inmiddels is er een nieuwe stal bijgebouwd deze is ingetekend als blauwe rechthoek ( $\mathrm{nr} 7$ ). De stal is meer dan 1 jaar oud. In de figuur zijn de bedrijfsgebouwen waar zich dieren in bevinden genummerd. In alle gebouwen worden vleesstieren gehouden. Waarbij nummer 7 de stal is waar de metingen plaats moeten vinden. Door de ligging van de bedrijfsgebouwen op dit bedrijf kunnen de metingen alleen plaats vinden bij zuidelijke wind (ZW tot ZO).

De stierenstal is ingericht met hokken waarin per hok een groep dieren wordt gehuisvest. Een hok bestaat uit een ingestrooid gedeelte en een dichte vloer. De stal is symmetrisch ingericht. Dit betekent aan 2 zijden een rij met hokken en in het midden een voergang. De combinatie van een ingestrooid deel (ingestrooid met stro) en dichte vloer wordt hellingstal genoemd waarbij de dieren het stro voor een deel uit de ingestrooide ruimte naar de dichte vloer lopen. Deze dichte vloer, ook wel mestgang genoemd, wordt wekelijks schoon gemaakt door middel van een shovel. Hierbij wordt de mest van de dichte vloer uit de stal verwijderd. Het instrooien van de ruimte wordt dagelijks gedaan. Hiervoor is een plafond aanwezig boven een deel van de hokken (over de hele lengte boven een deel van de ingestrooide ruimte). Op het plafond zijn strobalen geplaatst waarvan het stro wordt gebruikt voor het instrooien. De dieren worden eenmaal per dag gevoerd. De stal is natuurlijk geventileerd waarbij de inlaatopeningen aan beide lengte zijden van de stal zij aangebracht. De inlaat zit op ca $2 \mathrm{~m}$ en is ca $1 \mathrm{~m}$ hoog. De luchtinlaat wordt indien nodig beperkt door middel van een doek dat handmatig wordt bediend. De lucht gaat onder andere via de nok naar buiten. Door de aanwezigheid van strobalen in de ruimte zal de luchtbeweging in de stal worden beïnvloed. Door de metingen aan de uitgaande lucht in de buurt van de nok uit te voeren wordt ingeschat dat daar de lucht voldoende tijd heeft gehad om goed te mengen en daarmee de monstername goed kan plaats vinden. 
Tabel 3 Praktische informatie over meetstal 3.

\begin{tabular}{|c|c|}
\hline Stal afmetingen & $71,5 * 27,5 \mathrm{~m}$ \\
\hline Uitvoering & Hellingstal \\
\hline Indeling & $\begin{array}{l}\text { Aan iedere zijde } 17 \text { hokken; middenin een voergang } 5 \mathrm{~m} \\
\text { breed }\end{array}$ \\
\hline Ventilatie & Natuurlijk \\
\hline Regelbare luchtinlaat & Handmatig \\
\hline Dierplaatsen & 204 \\
\hline Groeitraject (mnd) & Gem. $10 \mathrm{mnd}$ (van ca $12 \mathrm{mnd}$ tot ca $24 \mathrm{mnd}$ ) \\
\hline Ras & Blonde d'Aquitaine \\
\hline Oppervlak / dier & $6,6 \mathrm{~m}^{2}$ \\
\hline Hokafmetingen & $4,2 * 11,0=46,2 \mathrm{~m}^{2}$ \\
\hline Opp strobed & $4,2 * 6,8=28,6 \mathrm{~m}^{2}$ \\
\hline Opp mestgang & $4,2 * 4,2=17,6 \mathrm{~m}^{2}$ \\
\hline Uitvoering mestgang & Dichte vloer \\
\hline Uitmestwijze & Shovel (handmatig) \\
\hline Uitmestfrequentie & $1 \times$ per week \\
\hline Instrooifrequentie & $1 \times$ per dag \\
\hline Wijze van instrooien & Handmatig \\
\hline Stroverbruik (kg/d) & 3 tot $4 \mathrm{~kg}$ \\
\hline Wijze \& frequentie voeren & $1 \times$ per dag \\
\hline Rantsoen & Gemengd \\
\hline Gemiddelde opname & $24 \mathrm{~kg} \mathrm{ds}$ \\
\hline
\end{tabular}

In onderstand plattegrond en doorsnede van een stierenstal staat globaal aangegeven op welke plekken de concentraties van ingaande lucht (achtergrondconcentratie en uitgaande lucht (stalconcentratie) gemeten zal worden.

: Meetpunt achtergrondconcentraties $\mathrm{NH}_{3}, \mathrm{CO}_{2}, \mathrm{~N}_{2} \mathrm{O}, \mathrm{CH}_{4}$ en PM10.

: Meetpunten stalconcentratie $\mathrm{NH}_{3}, \mathrm{CO}_{2}, \mathrm{~N}_{2} \mathrm{O}$, en $\mathrm{CH}_{4}$.

: Meetpunt PM10 stal en buiten 


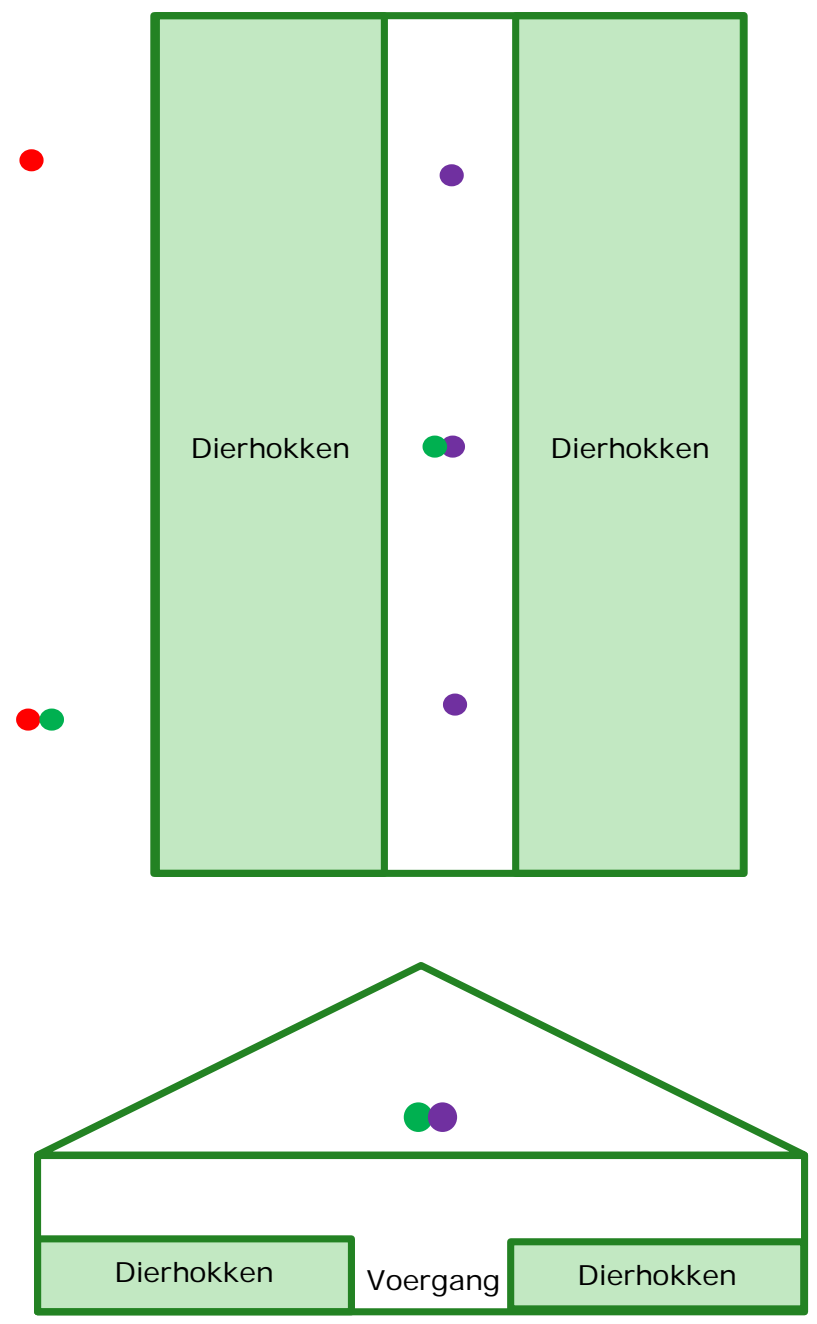




\section{Stal 4 - Bergentheim -}

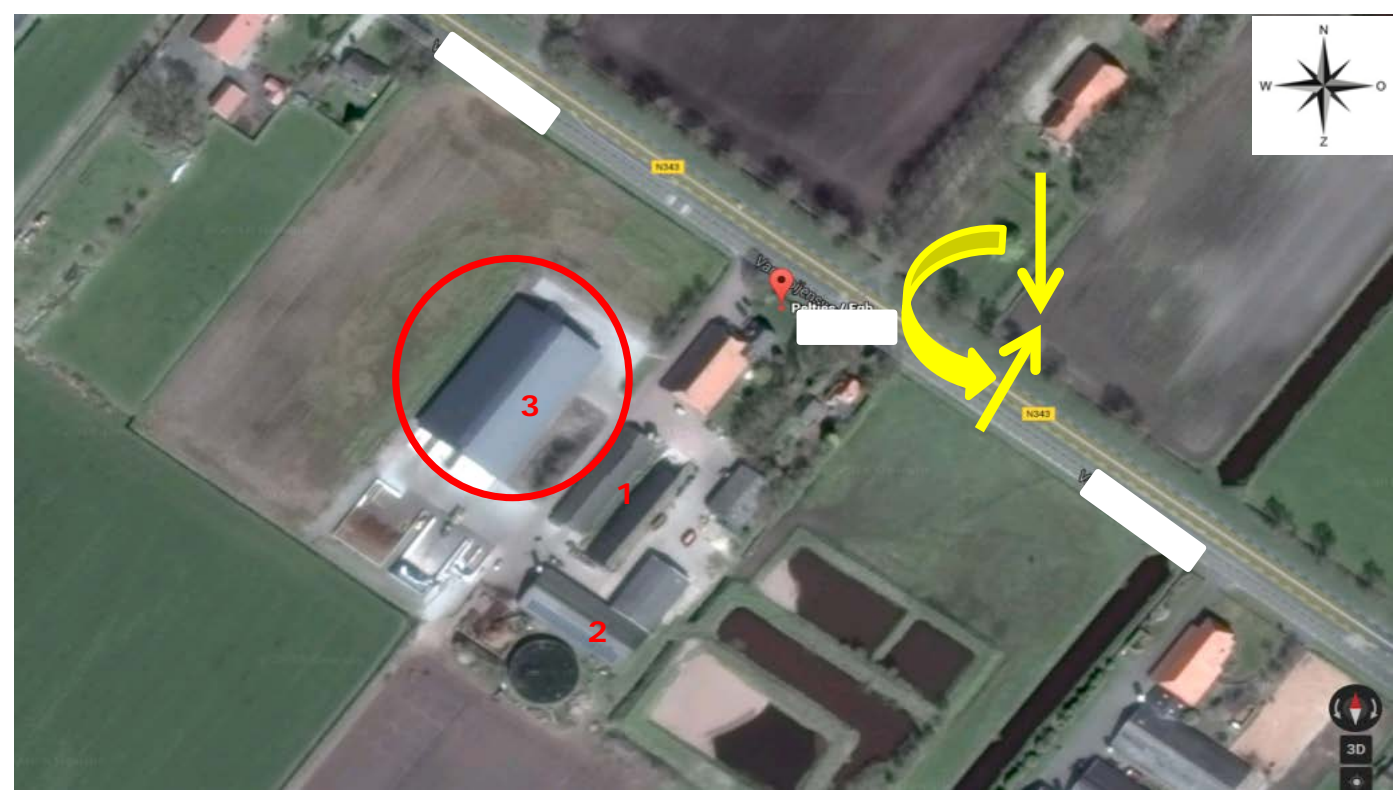

Figuur 4 Situatie stal 4 (stal met $\mathrm{nr} 3$ op de foto). De gele peilen duiden op de voorkeurs windrichting tijdens de metingen (ZZW - N).

In figuur 4 is de situatie weergegeven zoals deze op Googlemaps te vinden is. In de figuur zijn de bedrijfsgebouwen waar zich dieren in bevinden genummerd. In gebouw nummer $1 \mathrm{t} / \mathrm{m} 3$ worden vleesstieren gehouden. Waarbij nummer 3 de stal is waar de metingen plaats moeten vinden.

De meetstal is een openfrontstal met een nok. De stierenstal is ingericht met hokken waarin per hok een groep dieren wordt gehuisvest. Een hok bestaat uit een ingestrooid gedeelte en een dichte vloer. De hokken zijn verdeeld over 3 rijen. De openfront ligt aan de zijde van het erf, waar zich ook een voergang en een rij hokken bevindt. De tweede en derde rij hokken liggen parallel aan de eerste rij hokken waarbij de tweede en eerste rij tegen elkaar aan liggen. Tussen de tweede en derde rij bevindt zich weer een voergang. De combinatie van een ingestrooid deel (ingestrooid met stro) en dichte vloer wordt hellingstal genoemd waarbij de dieren het stro voor een deel uit de ingestrooide ruimte naar de dichte vloer lopen. Deze dichte vloer, ook wel mestgang genoemd, wordt 4 tot 5 maal per dag leeg geschoven met een mestschuif. Hierbij wordt de mest van de dichte vloer uit de stal verwijderd. Het instrooien van de ruimte wordt dagelijks automatisch gedaan met een instrooimachine. De dieren worden eenmaal per dag gevoerd.

De stal is natuurlijk geventileerd waarbij een inlaatopening aan de noordwestzijde van de stal zit. De inlaat zit op ca $2 \mathrm{~m}$ en is ca $1 \mathrm{~m}$ hoog. De luchtinlaat wordt indien nodig beperkt door middel van een doek dat handmatig wordt bediend. De lucht gaat onder andere via de nok en de openfront naar buiten. De metingen worden uitgevoerd aan de openfrontzijde ter hoogte van de hokrand van de eerste rij. De meethoogte betreft minimaal $3 \mathrm{~m}$ boven peil. Doordat er gemeten wordt bij een openfront kan er alleen worden gemeten bij de windrichting tussen noord en west in. 
Tabel 4 Praktische informatie over meetstal 4.

\begin{tabular}{ll} 
Stal afmetingen & $35 \times 58 \mathrm{~m}$ \\
Uitvoering & Hellingstal \\
\hline Indeling & Twee rijen met 15 hokken en 1 rij met 12 hokken \\
\hline Ventilatie & Natuurlijk \\
\hline Regelbare luchtinlaat & Handmatig \\
\hline Dierplaatsen & 195 \\
\hline Groeitraject (mnd) & Gem. 10 mnd (van ca 8 mnd tot ca 24 mnd) \\
\hline Ras & Blonde d 'Aquitaine \\
\hline Oppervlak / dier & $6,8 \mathrm{~m}^{2}$ \\
\hline Hokafmetingen & $4 * 8,5=34,0$ \\
\hline Opp strobed & $4 * 4,7=18,8 \mathrm{~m}^{2}$ \\
\hline Opp mestgang & $4 * 3,3=13,2 \mathrm{~m}^{2}$ \\
\hline Uitvoering mestgang & Dichte vloer \\
\hline Uitmestwijze & Automatisch mestschuif \\
\hline Uitmestfrequentie & 4 tot $5 \times$ per dag \\
\hline Instrooifrequentie & $1 \times$ per dag \\
\hline Wijze van instrooien & Automatisch \\
\hline Stroverbruik (kg/d) & 3 tot 4 kg \\
\hline Wijze \& frequentie voeren & $1 \times$ per dag \\
\hline Rantsoen & Gemengd \\
\hline Gemiddelde opname & $22 \mathrm{~kg}$ ds \\
\hline
\end{tabular}

In onderstand plattegrond en doorsnede van een stierenstal staat globaal aangegeven op welke plekken de concentraties van ingaande lucht (achtergrondconcentratie en uitgaande lucht (stalconcentratie) gemeten zal worden.

: Meetpunt achtergrondconcentraties $\mathrm{NH}_{3}, \mathrm{CO}_{2}, \mathrm{~N}_{2} \mathrm{O}, \mathrm{CH}_{4}$ en PM10.

: Meetpunten stalconcentratie $\mathrm{NH}_{3}, \mathrm{CO}_{2}, \mathrm{~N}_{2} \mathrm{O}$ en $\mathrm{CH}_{4}$

: Meetpunt PM10 in de stal en buiten

- : Nok 


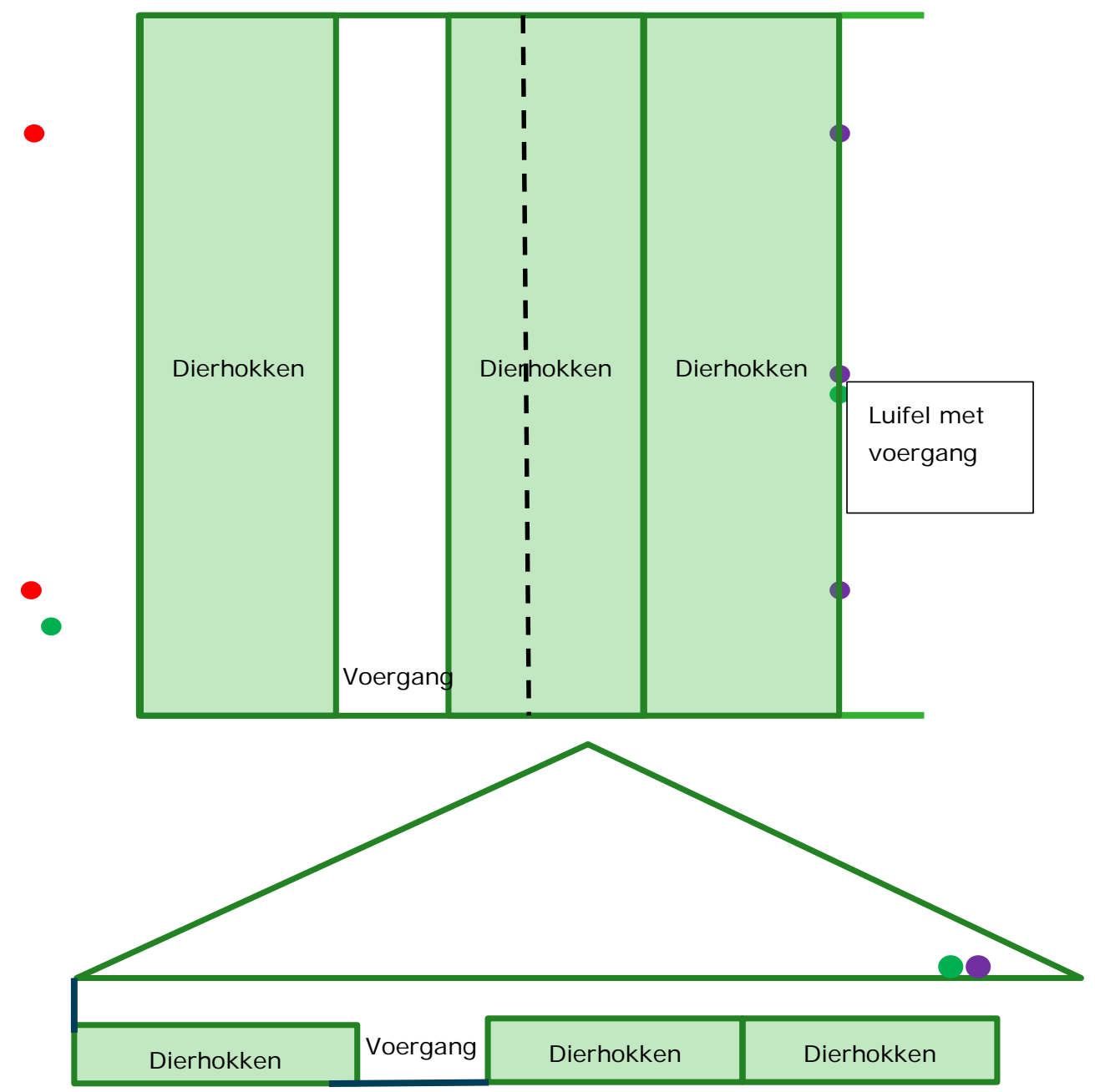




\section{Bijlage 2 Gedetailleerde meetdata rantsoen en $\mathrm{CO}_{2}$-productie}

Aanvulling Tabel 2 Ruwvoerrantsoen per locatie.

\begin{tabular}{|c|c|c|c|c|c|c|c|c|}
\hline & \multicolumn{2}{|l|}{ Stal 1} & \multicolumn{2}{|l|}{ Stal 2} & \multicolumn{2}{|l|}{ Stal 3} & \multicolumn{2}{|l|}{ Stal 4} \\
\hline & Ds (\%) & $\begin{array}{l}\text { Hoeveelheid } \\
(\mathrm{kg} \mathrm{ds} / \text { dier })^{1}\end{array}$ & Ds (\%) & $\begin{array}{l}\text { Hoeveelheid } \\
\text { (kg ds/dier) }\end{array}$ & Ds (\%) & $\begin{array}{l}\text { Hoeveelheid } \\
(\mathrm{kg} \mathrm{ds} / \text { dier })^{1}\end{array}$ & Ds (\%) & $\begin{array}{l}\text { Hoeveelheid } \\
(\mathrm{kg} \mathrm{ds} / \mathrm{dier})^{1}\end{array}$ \\
\hline \multicolumn{9}{|l|}{ Ruwvoer } \\
\hline Hooi & 85 & 0,9 & 90 & 0,7 & 85 & 0,9 & 85 & 0,4 \\
\hline Mais & 36 & 3,6 & 33 & 5,9 & 36 & 3,6 & 38 & 6,5 \\
\hline Bierborstel & 28 & 0,7 & - & - & 28 & 0,7 & 24 & 1,0 \\
\hline Aardappelsnippers & 24 & 0,5 & 22 & 1,0 & 24 & 0,5 & 22 & 1,1 \\
\hline maiskolfschroot & 55 & 1,1 & - & - & 22 & 0,4 & - & - \\
\hline Luzernekuil & 40 & 0,4 & - & - & 40 & 0,4 & - & - \\
\hline \multicolumn{9}{|l|}{ Krachtvoer } \\
\hline Krachtvoer 1 & 92 & 2,3 & 90 & 4,05 & 98 & 2,5 & 90 & 1,4 \\
\hline Krachtvoer 2 & - & - & - & - & - & - & 90 & 1,3 \\
\hline Droge pulp & 92 & 0,9 & - & - & 92 & 0,9 & - & - \\
\hline Tarwe & - & - & - & - & - & - & 90 & 0,9 \\
\hline
\end{tabular}

${ }^{1}$ gegevens middelste diergroep

Aanvulling Tabel $6 \quad \mathrm{CO}_{2}$-productie in het strobed per meetpunt.

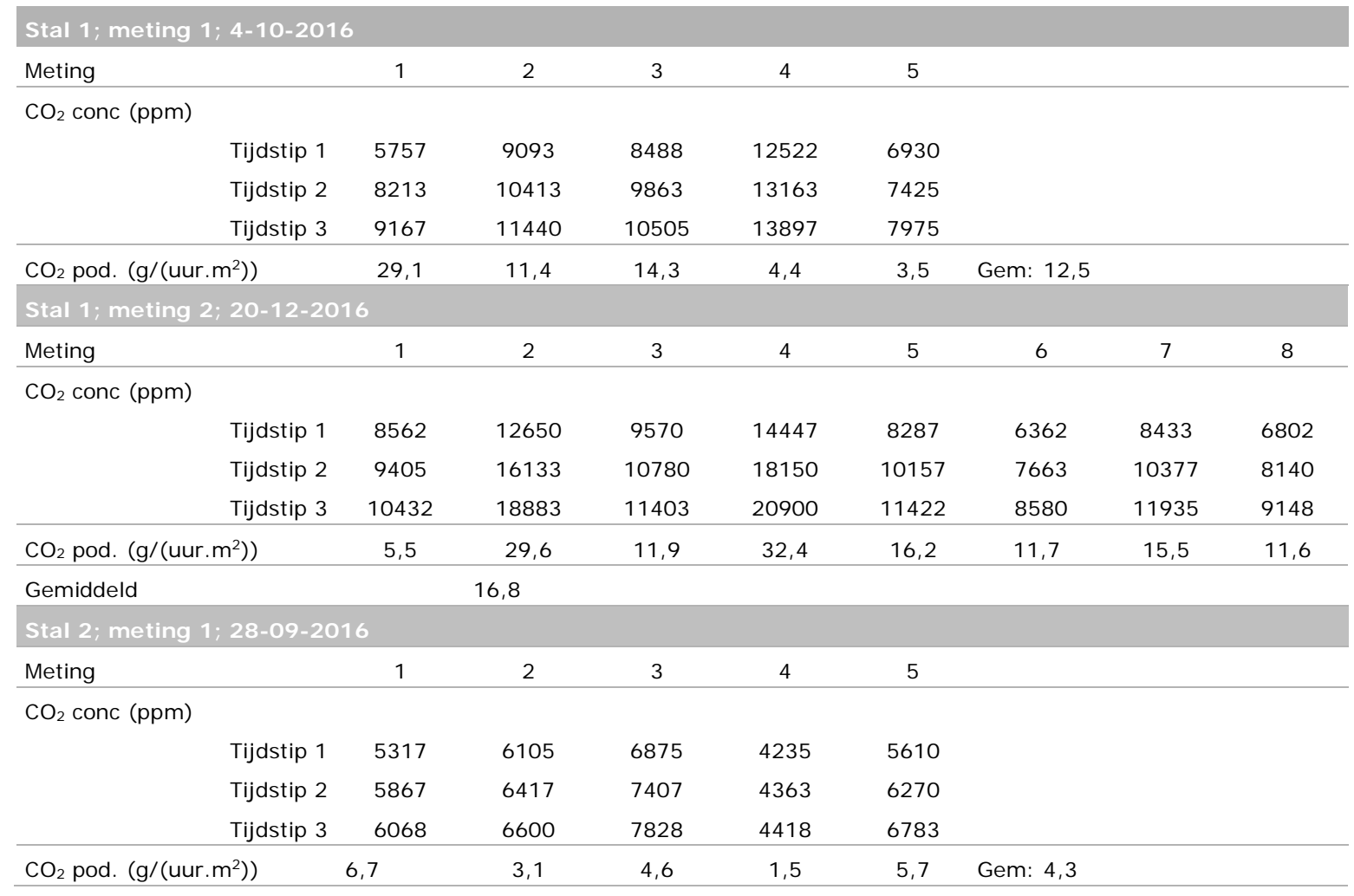




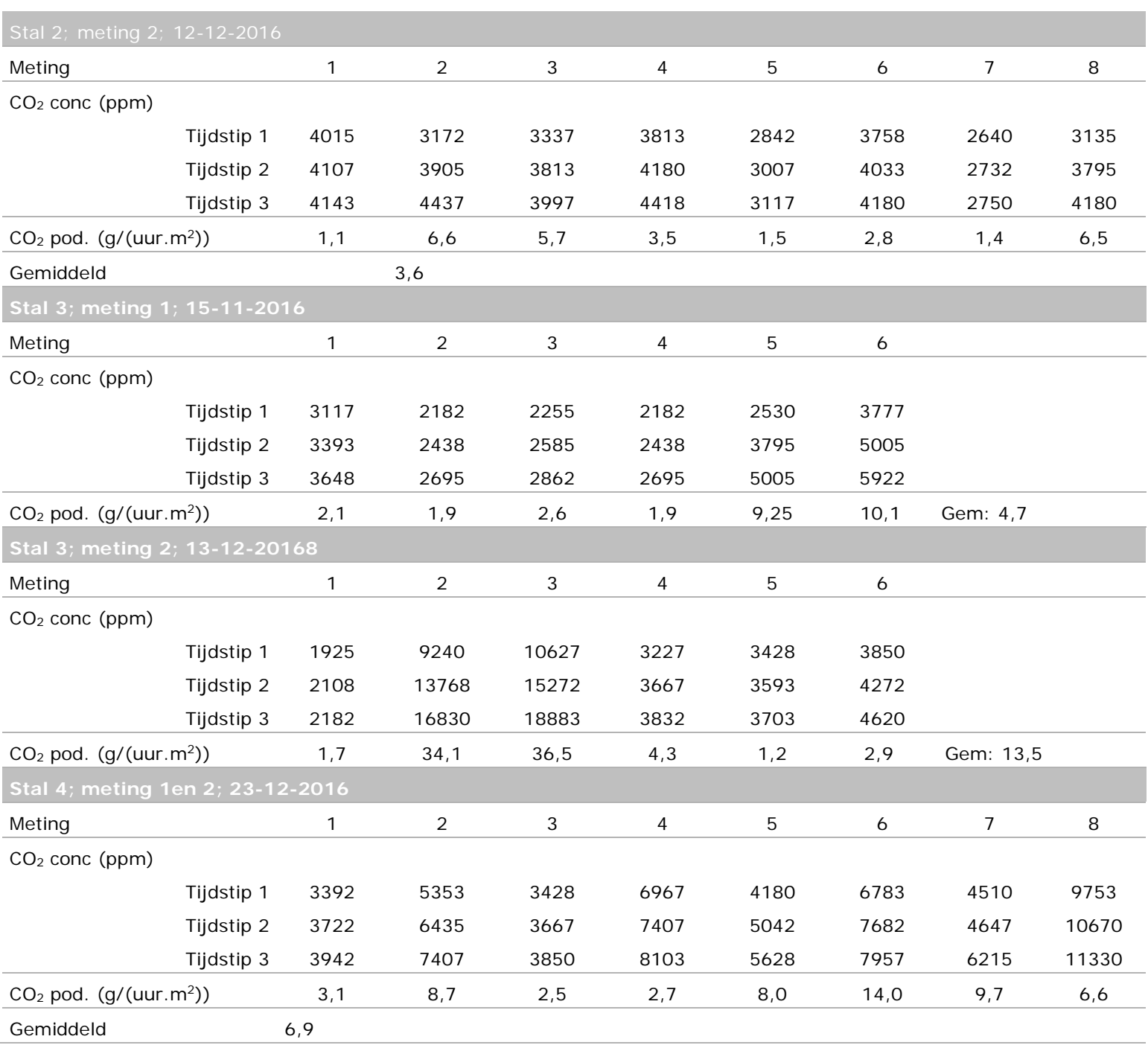



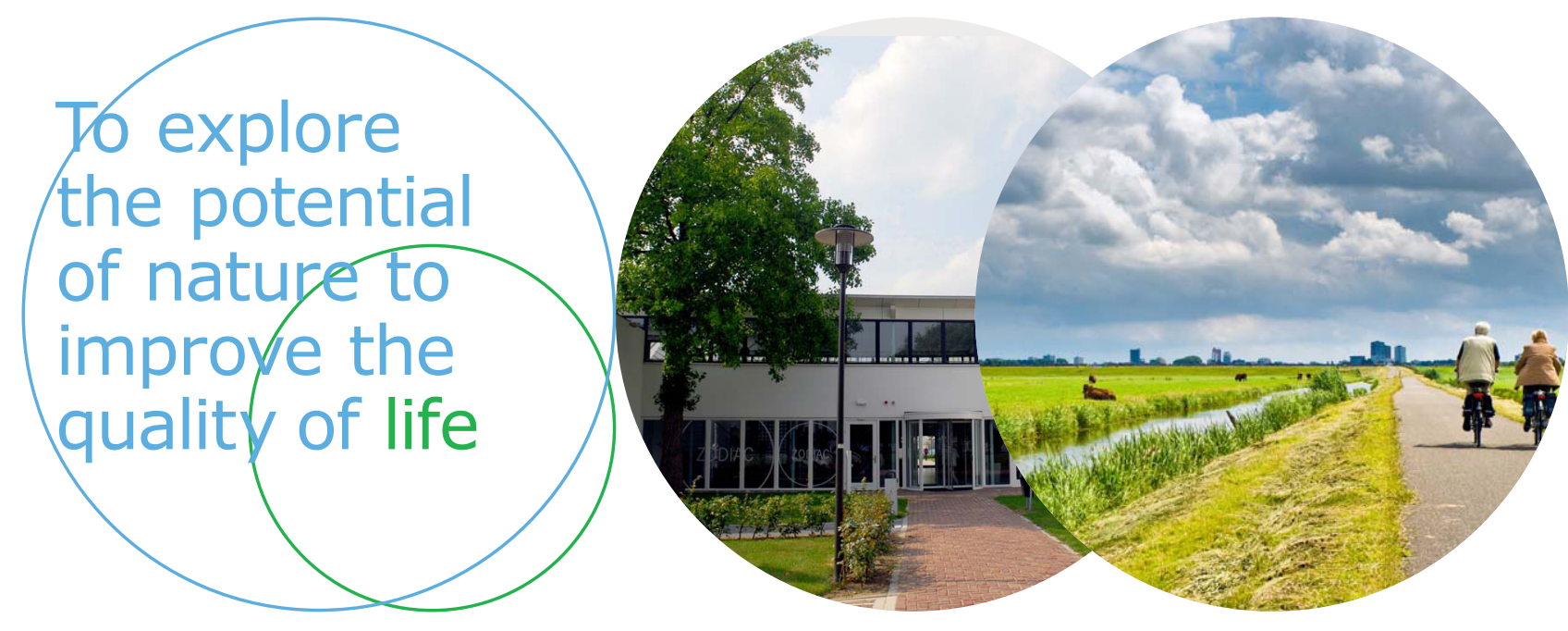

Wageningen Livestock Research Postbus 338

Wageningen Livestock Research ontwikkelt kennis voor een zorgvuldige en $6700 \mathrm{AH}$ Wageningen

T 0317483953

renderende veehouderij, vertaalt deze naar praktijkgerichte oplossingen en innovaties, en zorgt voor doorstroming van deze kennis. Onze wetenschappelijke

E info.livestockresearch@wur.nl www.wur.nl/ livestock-research kennis op het gebied van veehouderijsystemen en van voeding, genetica, welzijn en milieu-impact van landbouwhuisdieren integreren we, samen met onze klanten, tot veehouderijconcepten voor de $21 \mathrm{e}$ eeuw.

De missie van Wageningen University \& Research is 'To explore the potential of nature to improve the quality of life'. Binnen Wageningen University \& Research bundelen 9 gespecialiseerde onderzoeksinstituten van Stichting Wageningen Research en Wageningen University hun krachten om bij te dragen aan de oplossing van belangrijke vragen in het domein van gezonde voeding en leefomgeving. Met ongeveer 30 vestigingen, 6.500 medewerkers en 10.000 studenten behoort Wageningen University \& Research wereldwijd tot de aansprekende kennisinstellingen binnen haar domein. De integrale benadering van de vraagstukken en de samenwerking tussen verschillende disciplines vormen het hart van de unieke Wageningen aanpak. 